\title{
Breeding Progress for Vitamin A, Iron and Zinc Biofortification, Drought Tolerance, and Sweetpotato Virus Disease Resistance in Sweetpotato
}

\section{OPEN ACCESS \\ Edited by: \\ Willy Bayuardi Suwarno, \\ Bogor Agricultural \\ University, Indonesia \\ Reviewed by: \\ Victor Gaba \\ Agricultural Research Organization \\ (ARO), Israel \\ Hussein Shimelis, \\ University of KwaZulu-Natal, \\ South Africa \\ *Correspondence: \\ Robert O. M. Mwanga rmwanga7@gmail.com; \\ r.mwanga@cgiar.org}

Specialty section:

This article was submitted to

Crop Biology and Sustainability,

a section of the journal

Frontiers in Sustainable Food Systems

Received: 12 October 2020 Accepted: 18 January 2021

Published: 15 March 2021

Citation:

Mwanga ROM, Swanckaert J, da Silva Pereira G, Andrade MI, Makunde G, Grüneberg WJ, Kreuze J, David M, De Boeck B, Carey E, Ssali RT, Utoblo O, Gemenet $D$, Anyanga MO, Yada $B$, Chelangat DM, Oloka B, Mtunda K,

Chiona M, Koussao S, Laurie S, Campos H, Yencho GC and Low JW (2021) Breeding Progress for Vitamin

A, Iron and Zinc Biofortification,

Drought Tolerance, and Sweetpotato Virus Disease Resistance in Sweetpotato

Front. Sustain. Food Syst. 5:616674. doi: 10.3389/fsufs.2021.616674

\begin{abstract}
Robert O. M. Mwanga ${ }^{1 *}$, Jolien Swanckaert ${ }^{1}$, Guilherme da Silva Pereira ${ }^{2}$, Maria I. Andrade ${ }^{3}$, Godwill Makunde ${ }^{3}$, Wolfgang J. Grüneberg ${ }^{4}$, Jan Kreuze ${ }^{4}$, Maria David ${ }^{4}$, Bert De Boeck ${ }^{4}$, Edward Carey ${ }^{5}$, Reuben T. Ssali ${ }^{5}$, Obaiya Utoblo ${ }^{6}$, Dorcus Gemenet ${ }^{7}$, Milton O. Anyanga ${ }^{8}$, Benard Yada $^{8}$, Doreen M. Chelangat ${ }^{8}$, Bonny Oloka ${ }^{8}$, Kiddo Mtunda ${ }^{9}$, Martin Chiona ${ }^{10}$, Some Koussao ${ }^{11}$, Sunette Laurie ${ }^{12}$, Hugo Campos ${ }^{4}$, G. Craig Yencho ${ }^{13}$ and Jan W. Low ${ }^{2}$

1 International Potato Center (CIP), Kampala, Uganda, ${ }^{2}$ International Potato Center (CIP), Sub-Saharan Africa Regional Office, Nairobi, Kenya, ${ }^{3}$ International Potato Center (CIP), Maputo, Mozambique, ${ }^{4}$ International Potato Center (CIP), Lima, Peru, ${ }^{5}$ International Potato Center (CIP), Kumasi, Ghana, ${ }^{6}$ Department of Plant Science and Biotechnology, University of Jos, Jos, Nigeria, ${ }^{7}$ Excellence in Breeding Platform, Nairobi, Kenya, ${ }^{8}$ National Crops Resources Research Institute, National Agricultural Research Organization, Kampala, Uganda, ${ }^{9}$ Ministry of Agriculture, Food Security and Cooperatives, Tanzania Agricultural Research Institute, Tabora, Tanzania, ${ }^{10}$ Ministry of Agriculutre, Zambia Agricultural Research Institute, Mansa, Zambia, ${ }^{11}$ Crop Genetic and Biotechnology Lab, Institut de l'Environnement et de Recherches Agricoles (INERA), Ouagadougou, Burkina Faso, ${ }^{12}$ Agricultural Research Council-Vegetable and Ornamental Plants, Pretoria, South Africa,

${ }^{13}$ Department of Horticultural Science, North Carolina State University, Raleigh, NC, United States
\end{abstract}

Sweetpotato is a resilient food crop with great potential to contribute to reduced hunger in the world. Sweetpotato shows significant potential to contribute to reducing the Global Hunger Index, which reflects deficiencies in calories and micronutrients based on the components of hunger, undernourishment, under-five mortality rate, stunting and wasting. Its genetic diversity has been harnessed through breeding to increase vitamin A, iron, and zinc content, virus resistance and climate resilience for the world's food needs. Africa and India are the most food-insecure regions. The main objectives of this research were to: provide information and a knowledge base on sweetpotato breeding in Africa for biofortification of vitamin A, iron, and zinc, drought tolerance and virus resistance; recommend procedures for generating new breeding populations and varieties; and develop new tools, technologies and methods for sweetpotato improvement. The research was implemented between 2009 and 2020 in 14 collaborating African countries using introduced and local genotypes. The redesigned accelerated breeding scheme resulted in increased genetic gains for vitamin $A$, iron, zinc contents and virus resistance, and the release by sub-Saharan African countries of 158 varieties; 98 of them orange-fleshed; 55 varieties bred by an accelerated breeding scheme; 27 drought-tolerant and two with enhanced iron and zinc content. Our experience has demonstrated that through the use of more optimized, standardized and collaborative breeding procedures by breeding programs across Africa, it is possible to speed official sweetpotato variety release and contribute to reducing the severe micronutrient deficiencies on the continent.

Keywords: sweetpotato, breeding, biofortification, virus resistance, drought tolerance, quality 


\section{INTRODUCTION}

Sweetpotato [Ipomoea batatas (L.) Lam.] is a resilient food crop with great potential to contribute to reducing hunger in the world. Hunger typically refers to the distress associated with insufficient caloric intake given a person's sex, age, stature, and physical activity level (FAO, 2017). Undernutrition is a consequence of inadequate intake of nutritious food, poor utilization of nutrients due to infections or other illnesses, or a combination of these factors. This stems from a range of causes, including household food insecurity; inadequate maternal health or childcare practices; or insufficient access to health services, safe water, and sanitation. Sweetpotato, however, has many varieties that mature in $4-5$ months, enabling it to fit into many farming systems designed to alleviate the food insecurity.

Increasing emphasis is being focused on "hidden" hunger, the micronutrient deficiencies and resultant health consequences that are less visible than hunger caused by insufficient caloric intake. About half of children under five years of age in sub-Saharan Africa (SSA) suffer from vitamin A deficiency and $60 \%$ suffer from iron $(\mathrm{Fe})$ deficiency, the major cause of anemia and the most common micronutrient deficiency globally. Vitamin A deficient children are at higher risk of mortality and morbidity, and $\mathrm{Fe}$ deficiency in infancy and adolescence leads to impaired processing speed, learning capacity, memory and mental development (Fretham et al., 2011; Barrett and Bevis, 2015). Moreover, about one-third of the world population lives in areas at high-risk of zinc $(\mathrm{Zn})$ deficiency. $\mathrm{Zn}$ is vital for survival, especially during childhood when $\mathrm{Zn}$ requirements are increased. Zn deficiency can cause decreased immunity and increases the risk of stunting, common childhood infections and mortality (Roohani et al., 2013). Rather than focusing on individual micronutrient deficiencies, the Global Hunger Index reflects deficiencies in calories and micronutrients based on four hunger indicators: (i) undernourishment, (ii) under-five mortality rate, (iii) stunting, and (iv) wasting (Wiesmann et al., 2015). The countries most severely impacted by hunger are located in SSA and parts of Asia, especially India. Sweetpotato can be exploited through biofortification and other targeted breeding to increase its vitamin $\mathrm{A}$, iron, and zinc content, virus resistance and its climate resilience for the world's food needs.

"Biofortification is the process by which the nutritional quality of food crops is improved through agronomic practices, conventional plant breeding, or modern biotechnology. Biofortification of staple foods targets households most at risk of undernutrition and micronutrient malnutrition, which are mostly rural poor households that obtain most of their calories from staple foods they produce and consume" (Bouis et al., 2019). During the past two decades, there has been a significant global effort for breeding staple food crops to increase the density of the three major micronutrients, vitamin $\mathrm{A}, \mathrm{Fe}$, and $\mathrm{Zn}$ because of their critical importance to human health. To date, biofortified crops, namely, provitamin A-rich orange-fleshed sweetpotato (OFSP), iron beans, iron pearl millet, vitamin A yellow cassava, vitamin A orange maize, zinc rice, and zinc wheat, have been released in more than 30 countries and evaluation is underway and they are grown in more than
40 countries. Crop improvement targets varieties with higher levels of vitamins and minerals adapted to a wide range of agroecological conditions, and ensures that climate adapted germplasm and consumer-preferred traits are used in breeding biofortified crops (Siwela et al., 2020). Cultivated sweetpotato has great potential for enhancing the most essential vitamins and minerals because of the wide range of extant germplasm which can be bred for climate resilience and consumer preference.

The lead crop in the vitamin A biofortification effort has been OFSP. About $120 \mathrm{~g}$ of biofortified OFSP meets a young child's daily vitamin A needs (Low et al., 2020). The high amounts of $\beta$-carotene and its bioavailability in OFSP have been well-demonstrated over a decade ago (van Jaarsveld et al., 2005; Low et al., 2007; Hotz et al., 2012). Biofortification of sweetpotato with $\mathrm{Fe}$ and $\mathrm{Zn}$ could help in ameliorating negative effects of these micronutrient deficiencies, but the natural levels of iron and zinc found in OFSP germplasm were low. Hence, one of the objectives of SSA quality breeding effort since 2014 in Mozambique has been to develop sweetpotato clones with $25 \%$ of the recommended daily allowance of $\mathrm{Fe}$ and $35 \%$ of the recommended daily allowance of $\mathrm{Zn}$ for young children utilizing the accelerated breeding scheme, and to establish the bioavailability of $\mathrm{Fe}$ in sweetpotato roots. Sweetpotato clones with enhanced $\mathrm{Fe}$ and $\mathrm{Zn}$ can contribute to reducing the severe $\mathrm{Fe}$ and Zn deficiencies in SSA.

In addition, increased production and productivity of sweetpotato in SSA faces a number of constraints, both abiotic and biotic. Abiotic constraints, include inadequate and variable rainfall, sub-optimal temperatures associated with high and low elevation, and low soil fertility, while serious biotic constraints include viruses, mainly sweetpotato virus disease (SPVD), fungal diseases, mainly Alternaria bataticola blight, and sweetpotato weevils. Poor yielding varieties with little or no $\beta$-carotene also contribute to yield and nutrition gaps. Consumer preferences and gender (Mwanga et al., 2021) need to be concurrently considered for adoption to occur (Thiele et al., 2021). Quality traits related to storage root texture and storability are of particular importance. Hence, while biofortifying sweetpotato through breeding, it is also necessary concurrently to develop varieties that are welladapted to increasingly risky rainfed conditions, mainly drought, that are resistant to key diseases, especially viruses, and pests, and that have desired quality attributes to be widely adopted.

In SSA, SPVD, caused by the synergistic interaction of the whitefly-transmitted crinivirus, Sweet potato chlorotic stunt virus (SPCSV), and the aphid-transmitted potyvirus, Sweet potato feathery mottle virus (SPFMV), can cause losses of 50 to over $90 \%$ in many high-yielding susceptible genotypes (Karyeija et al., 1998; Clark et al., 2012). Field screening of sweetpotato germplasm for resistance to SPVD has mainly been based on symptom severity and incidence of SPVD infected plants following natural infection (Hahn et al., 1981; Aritua et al., 1998) although a root-grafting technique has been used under experimental conditions (Hahn et al., 1981). Field screening is problematic because vector populations fluctuate over seasons and years (Aritua et al., 1998; Clark et al., 2012) and roots are available only after completing a first seedling generation. Typically, large $(50,000-100,000)$ populations of $F_{1}$ seedlings 
require testing for several seasons for several years to identify agronomically superior genotypes with true SPVD resistance (Mwanga et al., 2013; Yada et al., 2017b). Initially, plants may escape infection, taking three or more years to show SPVD symptoms. This makes field screening for virus resistance slow and inefficient. A major complicating factor for virus control in sweetpotato is that farmers propagate the crop vegetatively using vine cuttings, thus providing opportunity to perpetuate systemic viruses. Symptom severity is the initial selection criterion for SPVD resistance, but may not be ideal where genotypes do not become systemically infected, and their virus titer is low at the time of evaluation (Clark et al., 2012). Discrimination of susceptible, tolerant and resistant genotypes, especially between the latter two in the absence of clear virus symptoms under different conditions, such as drought, remains a challenge.

Drought globally affects 52 million people annually, constraining sweetpotato production under rainfed conditions (Belesova et al., 2019). Climate change is predicted to increase the frequency and severity of droughts, especially in West Africa (Field et al., 2012). Southern Africa is mostly characterized by unimodal production systems with dry seasons lasting five months or longer, although several countries, such as Mozambique and Malawi are also vulnerable to flooding due to cyclones.

Drought is a complex phenomenon attracting different definitions depending on water use (Blum, 2011). Its occurrence and duration vary with location and season (Amede et al., 2004). Three main categories of drought in crop production have been identified, namely early season, mid-season and terminal, depending on the on-set of drought during crop growth and development (Ludlow and Muchow, 1990). For our purpose, drought means a shortage of water available in quantity and distribution to the sweetpotato crop, be it rainfall or soil moisture during the growing season. Drought trials are typically evaluated under two treatments, namely optimal irrigation, and drought treatment. Previous works described phenotyping for drought tolerance in sweetpotato (Laurie et al., 2013, 2015b; Omotobora et al., 2014; Andrade et al., 2016; Makunde et al., 2017). A deep understanding of the target population environments determines the success of breeding for drought tolerance. Sweetpotato suffers the most yield loss when exposed to early season drought during the establishment phase (1-4 weeks after planting) and storage root formation stage (4-6 weeks after planting) (Onwueme and Charles, 1994). These are the most critical times to focus on when evaluating for drought tolerance in sweetpotato. However, attention must also be paid in SSA on whether roots in the ground can sprout after the dry season, as it is a major method used by farmers to obtain planting material in drought-prone areas (Low et al., 2020).

Genetic variation for drought tolerance and sources of germplasm that contain enhanced expression of the desired trait are prerequisites for the development of drought tolerant sweetpotato varieties. In the current study, a germplasm panel was developed from farmer varieties or local landraces, international check clones, released varieties, and introductions from other countries. In view of the importance of sweetpotato in Mozambique and other countries in Southern Africa, the study was conducted to (i) develop a drought yield index for sweetpotato that takes account of mid-season drought for assessing the degree of genotypic variation for drought tolerance in 47 sweetpotato genotypes, and (ii) identify drought tolerant genotypes using drought indices as pre-breeding germplasm for future crossing blocks in Mozambique and candidate varieties for release in other countries with climatic conditions similar to Mozambique.

Although sweetpotato is one of the world's major food crops, investment in the development of genomic breeding resources for sweetpotato has been inadequate, and as a result it has often been referred to as an orphan crop. However, recent efforts have delivered a set of genomic tools for supporting sweetpotato breeding modernization. In addition to two wild diploid I. trifida and I. triloba reference genomes (Wu et al., 2018), and a first draft of the more complex I. batatas genome (Yang et al., 2017), there has been substantial progress concerning the discovery and analyses of single-nucleotide polymorphisms (SNPs) in sweetpotato DNA. More specifically, we are now able to perform quantitative genotype calling of thousands of SNPs derived from a genotyping-by-sequencing protocol modified for autopolyploids (Wadl et al., 2018). Such markers can be used in genetic analyses, such as linkage (Mollinari et al., 2020) and quantitative trait loci (QTL) mapping (Pereira et al., 2020). Altogether, these have been valuable tools when it comes to studying the genetic architecture of traits of interest, such as those related to sweetpotato $\beta$-carotene and starch contents (Gemenet et al., 2020a).

Exploiting the full potential of sweetpotato to contribute to improved nutrition in SSA requires addressing the causes of the yield gaps together with biofortification. In addition, recognizing that the dominant varieties are white-fleshed (having no $\beta$-carotene) or yellow-fleshed (with no or limited amounts of $\beta$-carotene and typically the presence of other carotenoids), factors concerning consumer acceptance must also be explicitly addressed in breeding efforts. Due to the widespread occurrence and severity of vitamin A deficiency in SSA, there have been concerted efforts since the 1990s to date in breeding adapted OFSP cultivars preferred by consumers with a genetic background suited for agroecologies with two of the major production constraints in SSA: SPVD and drought.

Sweetpotato breeding programs, similar to other breeding programs, continuously generate copious amounts of data on which they depend for critical breeding decisions. The increasing complexity of a modern genomic-assisted breeding program also requires the development of standard operating procedures as these are essential for implementing breeding data workflows, to ensure that all necessary breeding data follow a standard nomenclature or ontology (www.cropontology.org) to describe crop development and agronomic traits to facilitate analyzing and easy comparison of phenotypic and genotypic information across programs. There are numerous traits (total of 109 descriptors) in the sweetpotato ontology, including morphological (28), describing plant characteristics, such as leaf, flower, vine and root; agronomic performance (28), referring to vegetative and root characteristics; biochemical and quality (30) describing traits, such as protein, starch, individual sugars, vitamins (such as $\beta$-carotene) and minerals (such as iron and zinc), reaction to biotic stress (7), describing reaction 
to pests (such as sweetpotato weevil), and diseases (such as SPVD) (www.cropontology.org).

This paper focuses on progress in breeding for the needs of Africa in African countries. Our efforts have been focused in Africa during the past two decades due to the growing importance of sweetpotato on the continent and its ability to be adapted to meet the challenges of climate change, especially drought tolerance, and its potential for transformation for diversified use. Effective breeding programs require significant time and funding, but can provide very large returns on investment as improved varieties can benefit farmers, societies and the environment (Alston et al., 2020). Well-coordinated international breeding efforts with multiple partners, targeting major agroecologies or regionally important constraints have great potential to efficiently achieve great impact. Standardized information from teams, including experts, such as breeders, virologists, food scientists, gender specialists, statisticians, bioinformaticists, and economists on the performance of progenies and selected clones across environments assists breeders to efficiently make decisions about selection and variety releases. Standardized methods also facilitate the reporting of breeding program results to the governing authorities and supporting agencies. This work demonstrates the importance of bringing together teams to address problems in food systems and the developed methods which have worked, illustrating the importance of coordinating efforts to address hunger problems. Major lessons learned are also summarized. The main objectives of this research were to: provide information and a knowledge base on sweetpotato breeding in Africa for biofortification of vitamin A, iron, and zinc, drought tolerance and virus resistance; recommend procedures for generating new breeding populations and varieties; and develop new tools, technologies and methods for sweetpotato improvement. The research aimed at developing sweetpotato breeding procedures and genomic tools, redesigning and conducting trials for virus resistance, drought tolerance, and quality evaluation and ensuring efficient implementation in the collaborating African countries using introduced and local genotypes. The International Potato Center (known by its Spanish acronym CIP) collaborating with 14 national programs and other partners focused on developing common sweetpotato protocols and analytical tools with the following specific objectives:

1) Adapt an efficient population improvement scheme at subregional level in SSA linked with participatory varietal development at the national level for accelerated short and long-term production of new locally adapted varieties to significantly improve nutritional benefits to consumers;

2) Develop a protocol of breeding for virus resistance for the population development scheme;

3) Develop a protocol of breeding for drought tolerance in SSA for the population development scheme;

4) Develop a protocol of breeding for enhancement of quality traits, such as $\beta$-carotene, iron, and zinc (for the population development scheme);

5) Develop a protocol and genomic and digital tools for sweetpotato breeding.

\section{MATERIALS AND METHODS}

\section{Adapting Population and Variety Improvement Schemes}

Breeding and varietal improvement provide the basis for generating a radically expanded range of sweetpotato varieties that combine different quality characteristics with significant improvements in yielding ability. The traditional sweetpotato breeding scheme adapted from the International Institute of Tropical Africa (Hahn, 1982; Hahn et al., 1989) used by national programs across SSA countries, requiring 8-9 years from crossing to variety release, was redesigned as an accelerated breeding scheme to take less time, about 4 years. The concept of hybrid breeding in sweetpotato was first applied at the International Potato Center Headquarters in Peru in 2009, simultaneously generating three hybrid populations: (i) orangefleshed sweetpotato (OFSP) with wide adaptation and earliness, (ii) OFSP for high iron and zinc, and (iii) OFSP for low sweetness after cooking (Grüneberg et al., 2009a,b, 2015; Andrade et al., 2016; Low et al., 2020). The procedure centered around having more sites earlier in the breeding process, one of which was located in the stress environment of interest. The breeding scheme was redesigned at the support platforms to include pre-breeding and population improvement activities to develop populations, exploit heterosis or hybrid vigor leading to high trait means and genetic variation. The population development scheme was built around new breeding methods for sweetpotato and clonally propagated crops in general to accelerate the crossing and selection process and potentially allow the exploitation of heterosis in varietal development at the national level (Grüneberg et al., 2005, 2015).

The CIP and sweetpotato programs of the national agricultural research institutes coordinated and collaborated to improve methods and protocols (Grüneberg et al., 2009a, 2019). Three sub-regional sweetpotato support platforms, located in Uganda, Mozambique, and Ghana, were established in 2009 focusing on population improvement providing 14 national breeding programs with improved true-seed populations and superior parental material for major traits. Because of the high virus pressure found in bimodal rainfall zones, the virus resistance population development program was based in Uganda. Drought-tolerance breeding was based in unimodal Mozambique. In Ghana, emphasis was on the quality trait of low sweetness, containing 13-20\% sucrose equivalent (Kays et al., 2005), required in some processed products (not discussed in this paper), virus resistance and drought tolerance. All programs prioritized high $\beta$-carotene content, and beginning in 2014, studies in Mozambique included evaluation of $\mathrm{Fe}$ and $\mathrm{Zn}$ content. The national agricultural research institutes' breeding programs emphasized development and accelerated release of cultivars (Low et al., 2020), with the national breeding program in Uganda developing specific procedures for breeding for weevil resistance (Yada et al., 2017a), the major pest problem in SSA. In addition, all sub-regional and national programs prioritized selection of clones with high dry matter content, with desired minimum levels varying due to taste differences in different countries. 
Two genetically distinct and diverse sweetpotato populations were used as foundation for implementing a heterosis exploiting breeding scheme in Uganda. Population Uganda A (Pop Ug A) with 50 genotypes as male parents and Pop Ug B with 80 genotypes as female parents were established in 2010 at Namulonge in Uganda based on 31 simple sequence repeat (SSR) markers (David et al., 2018). Subsequent parental selections for population improvement used reciprocal recurrent selection focusing mainly on storage root yield and SPVD resistance in a heterosis exploiting breeding scheme described by Grüneberg and Swanckaert (2019) and Low et al. (2020). During the first five years of the population development at the platforms, barcoding was introduced as a quality control measure to track each genotype as it moved from screenhouse to field to laboratory. In Mozambique, two genetically distinct populations existed varying in origin and isolated by geography, one in the south for drought tolerance populations (Umbeluzi population) and another in central Mozambique (Gurue population) high in $\beta$-carotene, iron and other micronutrients. In 2017, diversity analysis of the parents constituting the two populations using SSR markers showed the genetic differences between the populations. A total of 50 parents were selected from each population to constitute a hybrid breeding program at Umbeluzi Research Station, combining drought tolerance with high $\beta$-carotene, iron, zinc, and dry matter.

\section{Development of a Procedure to Characterize Germplasm for SPVD Resistance \\ Sources of Inoculum and Plant Materials}

Based on literature (Aritua et al., 1998; Gibson et al., 1998; Clark et al., 2012), and confirmation of the virus species (Table 1) at the three sweetpotato support platforms based in Ghana, Mozambique, and Uganda, developing a procedure for identifying the resistance to the most problematic virus species, SPCSV and SPFMV was the focus. Different sweetpotato genotypes (1,410 in total) varying in resistance to SPVD obtained from CIP headquarters in Lima, Peru, were used to develop a scheme for grouping or characterizing sweetpotato germplasm in breeding populations in the field at the National Crops Resources Research Institute, Namulonge, in Uganda, a high SPVD pressure environment. At Namulonge five vine cuttings, each about $30 \mathrm{~cm}$ long, were planted on ridges $(1 \times 0.3 \mathrm{~m}$ on a ridge $)$ without replication in October 2010. In 2011, the genotypes were planted on single ridges ( 5 plants per plot) at Namulonge, Serere, and Kachwekano, and replicated three times at each location in May 2012. Serere is considered a low virus pressure location and Kachwekano low for virus pressure, but high for Alternaria blight pressure. Virus symptoms were recorded 4-6 weeks after planting based on a visual assessment recorded on a scale from 1 to 9 , where 1 indicates no virus symptoms, $2=$ unclear virus symptoms, 3 = clear virus symptoms at one plant per plot, $4=$ clear virus symptoms at two to three plants per plot, $5=$ clear virus symptoms at $5-10 \%$ of plants, $6=$ clear virus symptoms at $10-25 \%$ of plants, $7=$ clear virus symptoms at $25-50 \%$ of plants, $8=$ clear virus symptoms at nearly all plants per plot, $9=$ clear virus symptoms and clearly reduced growth in all plants. The second virus symptom scoring was done about 1 month before harvest (at 5 months after planting) as described by Grüneberg et al. (2009a). Twelve genotypes, plus NASPOT 11 used as a local check, were selected based on response to SPVD for validating and grouping or characterizing sweetpotato germplasm following SPVD infection.

\section{RNA Extraction From Sweeetpotato Leaves}

One SPVD diseased plant, when available, from each of three replications was sampled. The third expanded young leaf from the top of each plant was picked and the three leaves (one from each replication) formed a sample. RNA extraction was adapted from Lodhi et al. (1994). Briefly, fresh leaves in a 500-gauge polythene bag were ground with a hand roller, $10 \times(\mathrm{v} / \mathrm{w})$ of cetyl trimethylammonium bromide (CTAB) buffer was added, and the sample ground again. The samples were microfuged for $5 \mathrm{~min}$ at room temperature; then $700 \mu \mathrm{l}$ liquid was transferred to a fresh microfuge tube. An equal volume of chloroform:isoamyl alcohol (24:1) was added, mixed thoroughly, and microfuged for $5 \mathrm{~min}$. The upper aqueous layer was carefully removed to a fresh microfuge tube, without transferring any interphase. After repeating this step, an equal volume of $4 \mathrm{M} \mathrm{LiCl}$ was added, mixed and left overnight at $4^{\circ} \mathrm{C}$. The sample was microfuged for $20 \mathrm{~min}$ to collect RNA. The liquid was carefully removed leaving a pellet. Ethanol $(70 \%, 200 \mu \mathrm{l})$ was added and microfuged for $2 \mathrm{~min}$, then removed, leaving the pellet. The pellet was air-dried and resuspended in $100 \mu \mathrm{l}$ sterile distilled water. Extraction buffer consisting of 2\% CTAB, $100 \mathrm{mM}$ Tris- $\mathrm{HCl}, \mathrm{pH}$ 8.0, 20 mM EDTA, $1.4 \mathrm{M} \mathrm{NaCl}, 1.0 \% \mathrm{Na}$ sulphite (2.0\% polyvinylpyrrolidone-40) was added to aliquots of the sterilized stock buffer containing the first four components.

\section{Testing the Efficacy of Different Probes for Detection of SPCSV and SPFMV}

A total of four Taqman TAMRA probes and eight primers (Applied Biosystems) were used; the probes (P) targeted cyclooxygenase (Cox), an internal control, (COX-P) and one strain of SPCSV for East (E) Africa (SPCSV-Uni-E-P), one strain of SPCSV for West (W) Africa (SPCSV-Uni-W-P and one strain for SPFMV (SPFMV-Uni-847P). The eight primers were for two East (E) African SPCSV strains (SPCSV-Uni-E-F and SPCSVUni-E-R), two West (W) African SPCSV strains (SPCSV-Uni$\mathrm{W}-\mathrm{F}$ and SPCSV-Uni-W-R), two SPFMV strains (SPFMV-Uni818F and SPFMV-Uni-925R), and two COX internal controls (COX-F and COX-R). The probe and primer sequences are given in Table 2. RNA was standardized to $36 \mathrm{ng} / \mu \mathrm{l}$ in all samples. In all wells, 72 ng of RNA was used as template. A standard quantitative reverse transcription polymerase chain reaction (qRT-PCR) was run according to the manufacturer's recommendations; to directly relate threshold cycle $(\mathrm{Ct})$ values with virus titer, $1 / \mathrm{Ct}$ was computed.

\section{Gauging Progress in SPVD Resistance Breeding}

In 2018, three SPVD resistant parents selected from Pop Ug A, A50 (3A) were crossed in all possible combinations with five SPVD resistant parents selected from Pop Ug B, B80 (5B) and 
TABLE 1 | Virus species at the three sweetpotato support platforms based in Mozambique, Ghana, and Uganda.

\begin{tabular}{|c|c|c|c|}
\hline Virus species & Mozambique & Ghana & Uganda \\
\hline $\begin{array}{l}\text { Sweet potato feathery mottle virus } \\
\text { (SPFMV) }\end{array}$ & + & + & + \\
\hline Sweet potato collusive virus (SPCV) & + & + & + \\
\hline $\begin{array}{l}\text { Badnaviruses (Sweet potato (SP) } \\
\text { badnavirus a + SP badnavirus b) }\end{array}$ & + & + & + \\
\hline Sweet potato virus $C$ & + & + & + \\
\hline Sweet potato mastrevirus & + & + & + \\
\hline $\begin{array}{l}\text { Sweet potato chlorotic stunt virus } \\
\text { (SPCSV/-EAWA/MZ strains) }\end{array}$ & + & ++ & +++ \\
\hline $\begin{array}{l}\text { Sweet potato mild mottle virus } \\
\text { (SPMMV/EA/SA strains) }\end{array}$ & + & - & ++ \\
\hline $\begin{array}{l}\text { Sweet potato chlorotic fleck virus } \\
\text { (SPCFV/EAWA strains) }\end{array}$ & - & + & ++ \\
\hline Sweet potato virus G (SPVG) & + & - & - \\
\hline Sweet potato virus Z* (SPVZ) & + & - & - \\
\hline Sweet potato virus $W^{\star}$ (SPWW) & - & + & - \\
\hline
\end{tabular}

$+/-=$ virus present/virus absent, location: Mozambique (Maputo); Ghana (Fumesua); Uganda (Namulonge);,,$++++++=$ Same virus but different strains; *Sweet potato virus $Z$ (Valkonen et al., 2015) and Sweet potato virus $W$ are transmitted by aphids (Legg et al., 2017).

TABLE 2 | Probes and primers for the sweetpotato viruses evaluated at Namulonge in 2012, targeting COX (internal control) and different strains of Sweet potato chlorotic stunt virus (SPCSV) and Sweet potato feathery mottle virus (SPFMV).

\begin{tabular}{|c|c|}
\hline $\begin{array}{l}\text { Taqman TAMRA } \\
\text { probe }\end{array}$ & Sequences \\
\hline SPCSV-Uni-E-P & 5' -[FAM]-TCTGTCACGGCTACAGGCGACGTG-[TAMRA]-3' \\
\hline SPCSV-Uni-W-P & $\begin{array}{l}\text { 5'-[FAM]-CAAACGTAAGATAGCTCCCCAGTATTCCGTCAA- } \\
\text { [TAMRA]-3' }\end{array}$ \\
\hline SPFMV-Uni-847P & $\begin{array}{l}\text { 5'-[6-FAM]-AACGTCTCCACGCAAGAAGAGGATGC- } \\
\text { [TAMRA]-3' }\end{array}$ \\
\hline COX-P & 5' -[VIC]-TGCTTACGCTGGATGGAATGCCCT-[TAMRA]-3' \\
\hline \multicolumn{2}{|l|}{ Primers } \\
\hline SPCSV-Uni-E-F & 5'-CGGAGTITATTCCCACYTGTYT-3' \\
\hline SPCSV-Uni-E-R & 5'-GGGCAGCCYCACCAA-3' \\
\hline SPCSV-Uni-W-F & 5'-TCGAYAGACTGTCYTITGAAGAAA-3' \\
\hline SPCSV-Uni-W-R & 5'-TTATCAAAACRTCATTRCCTTCYAA-3' \\
\hline SPFMV-Uni-818F & 5'-CGCATAATCGGTTGTTGGTा-3' \\
\hline SPFMV-Uni-925R & 5'-TTCCTAAGAGGTTATGTATATTTCTAGTAACATCAG-3' \\
\hline COX-F & 5'-CGTCGCATTCCAGATTATCCA-3' \\
\hline COX-R & 5'-CAACTACGGATATATAAGAGCCAAAACTG-3' \\
\hline
\end{tabular}

Probes: cyclooxygenase (Cox); internal control (COX-P) and one strain of SPCSV for East (E) Africa (SPCSV-Uni-E-P), one strain of SPCSV for West (W) Africa (SPCSV-Uni-W-P) and one strain for SPFMV (SPFMV-Uni-847P). Primers: two East (E) African SPCSV strains (SPCSV-Uni-E-F and SPCSV-Uni-E-R); two West W) African SPCSV strains (SPCSV-UniW-F and SPCSV-Uni-W-R); two SPFMV strains (SPFMV-Uni-818F and SPFMV-Uni-925R) and two COX internal controls (COX-F and COX-R). Source: Mwanga et al. (2015).

their progeny (999 genotypes) were evaluated together with the B80 $\times$ A50 progeny (5,031 genotypes) in the subsequent three seasons (2018 through 2019) to estimate progress made based on best linear predictions for SPVD (overall mean scores), genotypic variance $\left(\sigma_{G}^{2}\right)$ and broad-sense heritability $\left(H^{2}\right)$ of parents and offspring and changes in the frequency of resistant genotypes in the populations. To compare SPVD resistance rating in the two progeny populations, their SPVD scores were transformed using logarithm due to skewness.

\section{Development of a Procedure to Characterize Drought Tolerance in SSA Study Material and Trial Design}

The study material consisted of 47 sweetpotato genotypes of which 14 were farmer varieties, 19 released varieties and one elite clone bred in Mozambique and 13 introductions from other countries (Table 3). The selection of farmer varieties was based on wide cultivation in dry regions of Mozambique and introductions based on the agronomic performance in field trials. All released varieties cultivated in Mozambique were included in the trial to assess their performance against landraces and introductions under drought conditions. The trials were planted in February 2015, August 2015, and September 2016 to avoid rainfall during root growth, from 40 to 70 days after planting (DAP). Two treatments were created, optimum irrigation and drought between 40 and 70 DAP. All the genotypes were evaluated together, planted in a randomized complete block design with two replications. The fields allocated to the trials at Umbeluzi Research Station of the national Instituto de Investigação Agrária de Moçambique had an even/uniform slope and blocks were easily formed. The trial area was divided into two blocks equal to the two treatments generated (optimum irrigation and drought). Each genotype was planted in four row plots, $5 \mathrm{~m}$ long and inter-row spacing of $0.9 \mathrm{~m}$ and intra-row spacing of $0.3 \mathrm{~m}$. No fertilizer was applied in any trial. All the genotypes were virus cleaned, multiplied from the tissue culture laboratory for valid testing of drought tolerance in the genotypes. The experimental plots were hoe weeded once a month until 60 DAP. Maximum and minimum temperatures, rainfall, and humidity were measured on daily basis using an automated $\mathrm{HOBO}$ weather station during the growing period. Both treatments received four furrow irrigations of $50 \mathrm{~mm}$ each: 1 day before planting, and 5,15 , and 25 DAP. The optimum irrigation treatment received additional furrow irrigations of $50 \mathrm{~mm}$ of water at 35,45 , and 55 DAP. Irrigation was resumed $70 \mathrm{DAP}$ in the drought treatment.

\section{Study Location}

The study was conducted at Umbeluzi Research Station, Boane, Maputo in Mozambique from 2015 to 2017 mostly during the dry season. Umbeluzi is located at latitude $26^{\circ} 05^{\prime} \mathrm{S}$, longitude $32^{\circ} 31^{\prime} \mathrm{E}$ and at an elevation of 12 meters above sea level. The soil at this site is alluvial with texture ranging from sandy loam in the top soil to sandy at $1.75 \mathrm{~m}$ soil depth and soil $\mathrm{pH}$ varies from 6 to 6.5 , optimum for sweetpotato production. Umbeluzi experiences a unimodal rainfall pattern with extended dry period from April to October with average monthly rainfall ranging from 0 to $150 \mathrm{~mm}$. Annual maximum and minimum temperatures range from 24.7 to 33 and 11.5 to $22.7^{\circ} \mathrm{C}$, respectively, based on the long-term weather records from Umbeluzi. High evapotranspiration is the 
TABLE 3 | List of sweetpotato germplasm evaluated for drought tolerance at Umbeluzi Research Station in 2015A, 2015B, and 2016 seasons.

\begin{tabular}{|c|c|c|c|c|c|}
\hline No. & Name & Origin & No. & Name & Origin \\
\hline 1 & Nhacutse 3 & Gaza (Xai-Xai) ${ }^{\star}$ & 25 & 199062.1 & $\mathrm{CIP}$ \\
\hline 2 & Caelan & CIP-Moz & 26 & Lo 323 & CIP \\
\hline 3 & Xiadla-xau & Gaza (Chokwe)* & 27 & Tio Joe & CIP-Moz \\
\hline 4 & Victoria & CIP-Moz & 28 & Namanga & CIP-Moz \\
\hline 5 & Nwamazambe & Gaza (Chokwe)* & 29 & Bela & CIP-Moz \\
\hline 6 & Nwamonguane & Gaza (Xai-Xai)* & 30 & Lourdes & CIP-Moz \\
\hline 7 & Nhacoongo1 & Gaza (Nhacoongo)* & 31 & Ininda & CIP-Moz \\
\hline 8 & Xihetamakote & Gaza (Chokwe)* & 32 & Irene & CIP-Moz \\
\hline 9 & Chissicuana 1 & Inhambane (Morrumbene)* & 33 & Cecilia & CIP-Moz \\
\hline 10 & Chissicuana 3 & Inhambane (Morrumbene)* & 34 & Erica & CIP-Moz \\
\hline 11 & Xitsekele & Inhambane (Homoine) ${ }^{*}$ & 35 & Margarete & CIP-Moz \\
\hline 12 & Xiphone & Inhambane (Morrumbene)* & 36 & Melinda & CIP-Moz \\
\hline 13 & Admarc & Zambezia* & 37 & Sumaia & CIP-Moz \\
\hline 14 & UNK-Malawi & Zambezia* & 38 & Jane & CIP-Moz \\
\hline 15 & Ivone & CIP-Moz & 39 & Gloria & CIP-Moz \\
\hline 16 & Maphuta & South Africa & 40 & Lawrence & CIP-Moz \\
\hline 17 & ST 87-030 & South Africa & 41 & 440203 & CIP \\
\hline 18 & Atacana & South Africa & 42 & MGCL01 & CIP/Tete* \\
\hline 19 & Cordner & Zimbabwe & 43 & Diliva & Gaza (Xai-Xai)* \\
\hline 20 & Chingova & Zimbabwe & 44 & Gaba-gaba & CIP-Moz \\
\hline 21 & SPK004 & Kenya & 45 & Tainung64 & CIP \\
\hline 22 & NASPOT 5 & Uganda & 46 & Japon & CIP \\
\hline 23 & Resisto & USA & 47 & Bita & CIP-Moz \\
\hline 24 & Anamaria & CIP-Moz & & & \\
\hline
\end{tabular}

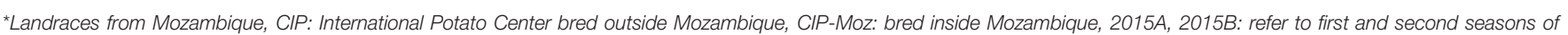
2015, respectively.

main feature of this site with between 2.8 and $7.2 \mathrm{~mm}$ lost daily (Gomes, 1996).

\section{Plant Trait Measurements}

Multiple plant traits were measured at different growth stages based on accepted sweetpotato trait ontology (http://www. cropontology.org/ontology/CO_331/sweetpotato). The traits were: (1) vine internode length (VINLG) and (2) plant length measured using a measuring tape on the length of the main vines (PLANT); (3) vine internode diameter (VINDIA) using a Vernier caliper between the soil surface and junction where the second branch intersected with the stem and expressed in $\mathrm{mm}$; (4) storage root weight $(\mathrm{kg})$ expressed as storage root yield in tons per hectare (RYTHA); (5) vine weight (kg) expressed as foliage yield in tons per hectare (FYTHA). In addition to individual genotype measurements, drought intensity index (DII) calculated as DII $=\left[1-\left(\bar{Y}_{D S} / \bar{Y}_{N S}\right)\right]$, where $\bar{Y}_{D S}$ and $\bar{Y}_{N S}$ are the mean storage root yield of all genotypes under drought stress and non-stress treatments, respectively (Fischer and Maurer, 1978), was used to quantify the severity of drought stress on storage root yielding ability of the genotypes. Harvest index (HI) was computed as a percentage, determined as the ratio of RYTHA at harvest over the weight of total biomass (FYTHA + RYTHA) at harvest multiplied by 100 . Drought stress tolerance was calculated for the genotypes. Rosielle and Hamblin (1981) defined stress tolerance (TOL) as differences in yield between the stress and non-stress environments $\left(T O L=Y_{N S}-Y_{D S}\right)$. Higher TOL values indicate susceptibility of a cultivar. Ramirez-Vallejo and Kelly (1998) proposed a geometric mean of productivity (GMP) as the square root of the product of yield under stress $\left(Y_{D S}\right)$ and yield under non-stress conditions $\left(Y_{N S}\right): G M P=\sqrt{Y_{D S} \times Y_{N S}}$. The index is good when testing performance under optimum and drought stress environments considering drought variability among locations and years. A stress susceptibility index (SSI) that assesses the reduction in yield caused by stress compared with optimum conditions, as suggested by Fischer and Maurer (1978) was estimated among the genotypes. SSI was computed as $S S I=\left[\left(1-Y_{D S} / Y_{N S}\right) / D I I\right]$. Lower SSI values indicate more tolerance to drought.

\section{Statistical Analysis}

The analyses of variance for the variables collected under both optimum irrigation and mid-season drought stress and phenotypic correlations between storage root yield ( $t / h a)$ and other traits were conducted using SAS software (SAS, 1997). Genotypes were considered as fixed to get best linear unbiased estimates using the residual maximum likelihood procedure. 


\section{Development of a Procedure of Breeding for High Iron and Zinc}

An intra-gene pool crossing block with eight males and 60 females was established at Umbeluzi Research Station in Mozambique in 2015 following the North Carolina Design II (Comstock and Robinson, 1952). The reciprocal recurrent selection method was deployed for population improvement in crossing blocks and population means have shifted from 0.98 to $2.7 \mathrm{mg} / 100 \mathrm{~g}$, dry weight (DW) Fe, and 0.60 to $1.3 \mathrm{mg} / 100 \mathrm{~g}$, DW $\mathrm{Zn}$ in Mozambique. Hand crosses were made and produced a total of 12,858 botanical seeds. Families with more than 20 seeds per family were selected for field evaluations. A total of 20 botanical seeds were selected per family from 150 families, scarified and germinated in 2015 in a greenhouse in Maputo, Mozambique. In total, 3,000 botanical seeds were germinated to produce clones. The germinated 3,000 clones were cut and rapidly multiplied in open field. Each clone was expected to produce six cuttings of $30 \mathrm{~cm}$ long each after 60 days.

\section{Field Evaluations and Agronomic Management}

Sweetpotato breeding standard operating procedures for field evaluations were followed (Grüneberg et al., 2009a, 2015). About 3,000 clones were planted in observation trials at Umbeluzi Research Station under two distinct treatments, namely optimum irrigation and mid-season drought in March 2016. The observation trials had $1 \mathrm{~m}$ long plots and unreplicated in each treatment. Plant spacings were $0.9 \mathrm{~m}$ intra-row and $1 \mathrm{~m}$ inter-row. Three plants were planted in each plot. No fertilizers were applied in either treatment, and weeds were controlled by hoe weeding. Both treatments received four furrow irrigations of $50 \mathrm{~mm}$ each: 1 day before planting, and 5, 15, and 25 DAP. The optimum irrigation treatment received additional furrow irrigations of $50 \mathrm{~mm}$ of water at 35, 45, and 55 DAP. Irrigation was resumed 70 DAP in the drought treatment.

\section{Storage Root Sampling for Analysis of Quality Traits}

The standard operating procedure for sampling of storage roots in the field and their subsequent nutrient analysis in the laboratory developed by Porras et al. (2014) was adapted by the Southern Africa Sweetpotato Support Platform in Mozambique. At harvesting, three storage roots were selected to represent the plot as a sample and packed in a well-labeled khaki bag, showing the trial name, clone name, plot number, replication and location. Acceptable root sizes for laboratory processing ranged between 200 and $300 \mathrm{~g}$ per root. Samples from the 6,000 clones in the optimum irrigation and mid-season drought treatments were collected and sent to the laboratory for nutrient analysis.

Each sample was washed and dried separately on arrival at the laboratory. After drying, the samples were peeled and $50 \mathrm{~g}$ of fresh weight from the peeled three roots combined was determined by weighing and proceeded to freeze drying for $72 \mathrm{~h}$. After freeze drying, the samples were weighed again (dry weight reading). Dry matter (\%) of a sample was calculated based on the two weights (fresh and dry weights) expressed as a percentage. The dried samples were ground by hand into powder form. Samples from the ground powder were read in the nearinfrared spectroscopy (NIRS) machine to determine Fe and $\mathrm{Zn}$ contents among other micronutrients, protein, starch and simple sugars. Samples of $20 \mathrm{~g}$ powder were drawn from the samples which had high iron and zinc contents from NIRS, packaged and sent to CIP-Lima for X-ray fluorescence (XRF) analysis. Further $10 \mathrm{~g}$ powder were drawn from samples which had high iron and zinc contents after XRF analysis and sent to Australia for inductively coupled plasma (ICP) analysis and confirmation that contamination was not interfering with $\mathrm{Fe}$ and $\mathrm{Zn}$ results (Porras et al., 2014).

\section{Development of Genomic and Digital Tools for Sweetpotato Breeding \\ Mapping Population and Linkage Analysis}

The "Beauregard" $\times$ "Tanzania" (BT) mapping population was comprised of 315 progenies and has been described previously (Gemenet et al., 2020a). In brief, "Tanzania" is a cream-fleshed landrace from SSA, whereas "Beauregard" is an orange-fleshed American cultivar. The BT population was genotyped using a genotyping-by-sequencing protocol adapted for polyploids, called GBSpoly (Wadl et al., 2018; Mollinari et al., 2020). This protocol supported marker dosage calling using the software SuperMASSA (Serang et al., 2012) through VCF2SM wrapper script (Pereira et al., 2018). A total of 30,684 markers were ultimately used for integrated linkage map construction using MAPpoly R package (Mollinari et al., 2020), and spanned 2,708.3 cM covering 15 linkage groups (available at https://gt4sp-genetic-map.shinyapps.io/bt_map/). Genotype conditional probabilities were calculated every $\mathrm{cM}$ along the genetic map for QTL mapping purposes using a hidden Markov model adapted for autopolyploids (Mollinari and Garcia, 2019).

\section{Phenotypic Data}

In Ghana, field trials were conducted under optimal conditions in 2016 in Fumesua $\left(6^{\circ} 42^{\prime} 39.41^{\prime \prime} \mathrm{N}, 1^{\circ} 31^{\prime} 2.03^{\prime \prime} \mathrm{W}\right.$; rainfed), and in 2017 and 2018 in Nyanpkala $\left(9^{\circ} 24^{\prime} 0^{\prime \prime} \mathrm{N}, 0^{\circ} 58^{\prime} 60^{\prime \prime} \mathrm{W}\right.$; irrigated), located in the forest and savanna ecozones, respectively. The trial in Fumesua was planted as a randomized complete block design with three replications ( 245 progenies plus one of each parent per replication), whereas the trials in Nyanpkala were each planted as an $\alpha$-lattice design with two replications (266 progenies plus two of each parent per replication). After harvest, sweetpotato storage roots were washed and aired. Then, they were peeled, quartered, and sliced thinly using a vegetable grater. Thin root slices were bagged, labeled, and freeze dried at $-31^{\circ} \mathrm{C}$ for $72 \mathrm{~h}$ using a vacuum freeze dryer. The dry samples were weighted and milled into flour using a stainless-steel mill. Finally, the storage root biofortification traits ( $\beta$-carotene, $\mathrm{Fe}$, and $\mathrm{Zn}$ contents) were determined using NIRS at CIP-Ghana in Kumasi.

\section{Phenotypic Analysis}

A two-stage analysis was carried out with the NIRS raw data. In the first stage, each trial was analyzed separately using a mixed model with the genotype as fixed effects and the design components (blocks, replications, error) as random effects. In the second stage, both adjusted means and weights from the first stage were used in a mixed model with genotype $(G)$ as fixed effects, and environment $(\mathrm{E})$ and $\mathrm{G} \times \mathrm{E}$ interaction as random 
effects. The weights were based on the diagonal of the variancecovariance inverse matrix from each first-stage model (Method 4 of Möhring and Piepho, 2009). The adjusted means from the second stage were then used to compute Pearson's correlation between traits, and, together with the weights, perform QTL analysis as described next. Measures of genotype-mean broadsense heritability were computed per trait for each trial (firststage model with genotypes as random effects) as $H^{2}=\sigma_{g}^{2} /\left(\sigma_{g}^{2}+\right.$ $\left.\sigma_{e}^{2} / R\right)$, where $\sigma_{g}^{2}$ and $\sigma_{e}^{2}$ are the respective genetic and residual variances, and $R$ is the number of replications.

\section{QTL Analysis}

For each trait, we ran a weighted random-effect multiple interval mapping (REMIM) model using the QTLpoly R package (Pereira et al., 2020). Score statistics were used to test whether the variance component associated with a putative QTL was significant or not. Putative QTL were fitted every $\mathrm{cM}$ position along the BT genetic map, and a 20-cM window on each side of QTL already in the model was avoided when searching for another QTL. A stepwise algorithm was used to either add (forward search) or exclude (backward elimination) a QTL considering genome-wide thresholds of 20 or $5 \%$, respectively, which were assessed using a score-based resampling method (Zou et al., 2004). Once the final multiple QTL model was obtained, the breakdown of genotypic values of each QTL was used to compute additive allele effects (Pereira et al., 2020).

\section{Development of Digital Tools for Sweetpotato Breeding}

The CIP, the collaborating national sweetpotato breeding programs in SSA and other partners, such as North Carolina State University, Michigan State University, and the Boyce Thompson Institute for Plant Research at Cornell University collaborated at different levels to develop the standard operating procedures for data recording and data management in sweetpotato breeding activities. These activities included: phenotyping, electronic data capture using Field Book (Rife and Poland, 2014), crossing, NIRS quality assessment, germplasm management and DNA sample management. The targeted traits varied by support platform, sub-region and country and included data, such as storage root yield, foliage yield, biomass, harvest index, storage root dry matter content, number of commercial roots per plant, storage root shape and form, flesh color (such as purple and orange) and skin color, protein, starch, individual sugars, vitamins (such as $\beta$ carotene) and minerals (such as Fe and $\mathrm{Zn}$ ), resistance to pests (such as sweetpotato weevil), and resistance to diseases (such as SPVD).

\section{RESULTS}

\section{Adapting Population Improvement and Variety Improvement Schemes}

At the East and Central African Sweetpotato Support Platform at Namulonge in Uganda, the best sweetpotato parents, 20 from population A and 20 from population B were selected based on performance of offspring and flesh color ( $\beta$-carotene) of Pop Ug A (50 parents) and Pop Ug B (80 parents). The 20 parents from Population Uganda A were: Carrot C, Ejumula, Mayai,
KMI61, MPG1128, KBL648, RAK819, NASPOT 9 O, Tororo 3, RAK808, LUW1274, NASPOT 7, NASPOT 10 O, KML872, Oguroiwe, APA323, Otada, RAK835, NK318L, and MLE194. The 20 parents from Population Uganda B were: ARA29, SRT43, MLE199, KML942, LUW1257, KRE691, MBR536, MLE179, Sowola, APA356, MKN121, NASPOT 5, SPK004, RAK848, MSK194, NASPOT 11, Jewel, Resisto, Raihna, and CIP199062.1. The parents were selected for population improvement using reciprocal recurrent selection focusing mainly on storage root yield and SPVD resistance in a heterosis exploiting breeding scheme described earlier under "Materials and Methods" (above).

Following the procedures developed and validated at the regional sweetpotato support platforms based in Mozambique, Ghana, and Uganda, seven out of 16 SSA sweetpotato breeding programs implemented and released 55 improved varieties using the accelerated breeding scheme between 2009 and 2020 (Table 4). Out of 158 varieties released during the same period, 98 were OFSP, six were purple-fleshed (rich in anthocyananins important as antioxidants) and 54 were of other root flesh colors, such as white and yellow. Twenty-seven of the varieties were drought tolerant; two of them with enhanced iron and zinc. Most of the released varieties were local landraces or bred by accelerated breeding scheme or introductions from African breeding programs (Figure 1). Two of the most popular varieties, "Irene," released in Mozambique, has been released in Côte d'Ivoire, Kenya, Madagascar and Rwanda, and the variety, "Kabode," released in Uganda, has been released in Ethiopia, Kenya, Rwanda, and Tanzania. Improved varieties were bred by national programs to meet the needs of farmers and consumers specific for their respective countries, combining different traits, such as high dry matter ( $30 \%$ and above), resistance to diseases, high $\beta$-carotene content, drought tolerance and yield. Individual countries also considered gender and included traits specific to the preferences of their end users, such as growth type, quality of leaves for consumption, and root characteristics, such as shape, sweetness and mealiness. To start the accelerated breeding scheme, 10 of the national sweetpotato breeding programs were funded by the Alliance for a Green Revolution in Africa (AGRA) for about three years commencing 2009/2010.

\section{SPVD Resistance}

Results of the field evaluation at Namulonge in Uganda for SPVD resistance of 12 genotypes screened from 1,410 genotypes are shown in Table 5. Five of the 12 clones 11.7, 17.3, 21.4, 23.11, and 24.7, had SPVD mean scores of about 3 or less. The check clone, NASPOT 11 had SPVD mean score of 2.7. All the other genotypes had mean SPVD scores 4.0 and above.

Real time PCR (qRT-PCR) analysis results of leaf samples from the same clones are shown in Table 5. Out of the 12 genotypes, only three, $17.3,20.8,24.7$, and the check clone had low virus titer; the threshold value for clones considered to be resistant was three times the value of the negative control. Although genotype 17.3 (6.1 t/ha), and 24.7 (5.4 t/ha) had low virus titer accumulation they had very low root yields compared to the check, NASPOT 11 (17.4 t/ha). Genotypes 21.4 (16.2 t/ha) and 23.11 (19.9 t/ha) had high storage root yield, low SPVD symptoms but high virus titer. 
TABLE 4 | Sweetpotato varieties released in sub-Saharan Africa during 2009 to 2020 as local landrace (LLR), introduced African landrace (ILA), introduced exotic landrace (ILX), bred in country using traditional breeding scheme (TBS) or participatory plant breeding (PPB), accelerated breeding scheme (ABS) or selected from introduced seed from an African breeding program (ISA), introduced clone from African breeding program (ICA), introduced clone from non-African breeding program (ICX).

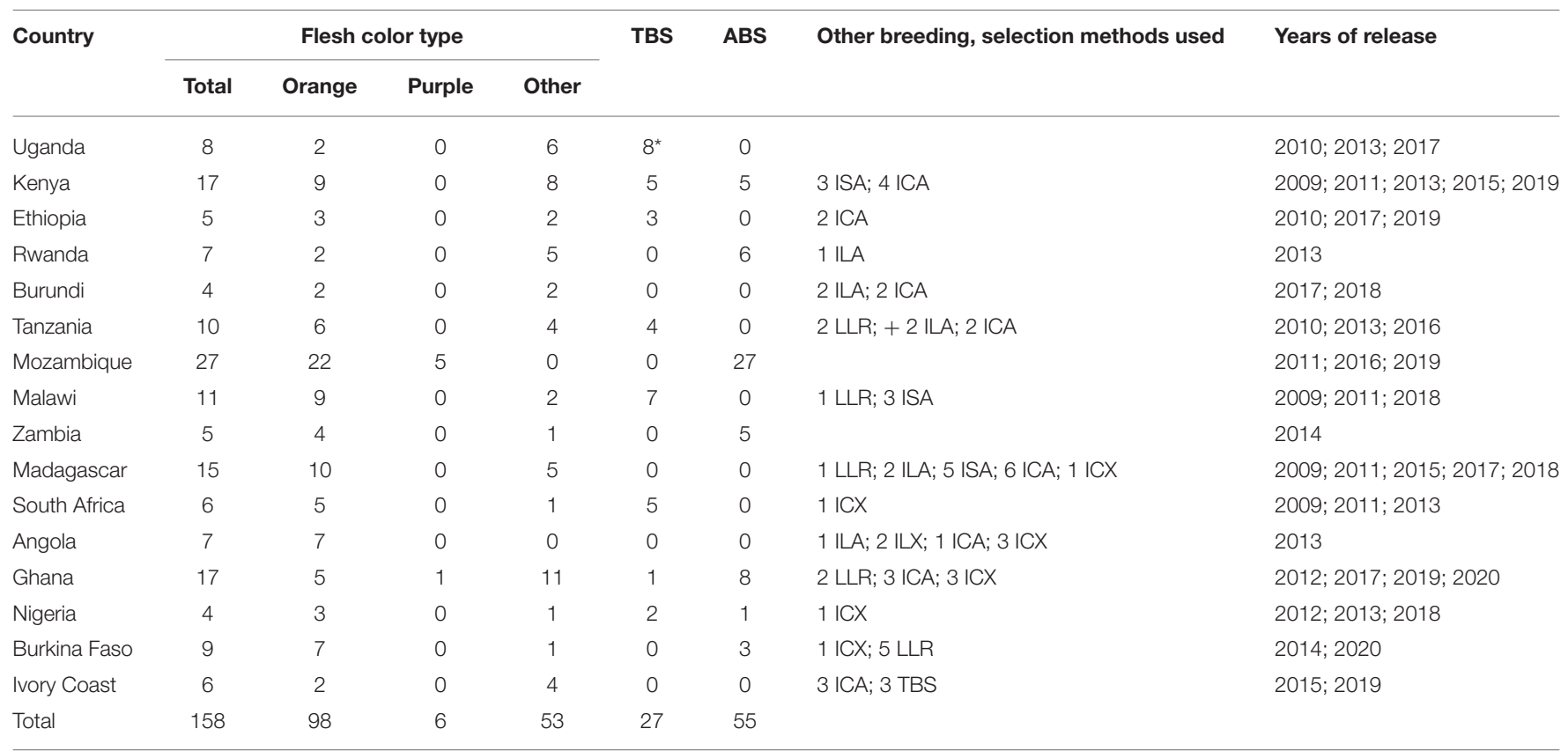

*One variety from Uganda was developed through a participatory plant breeding process.

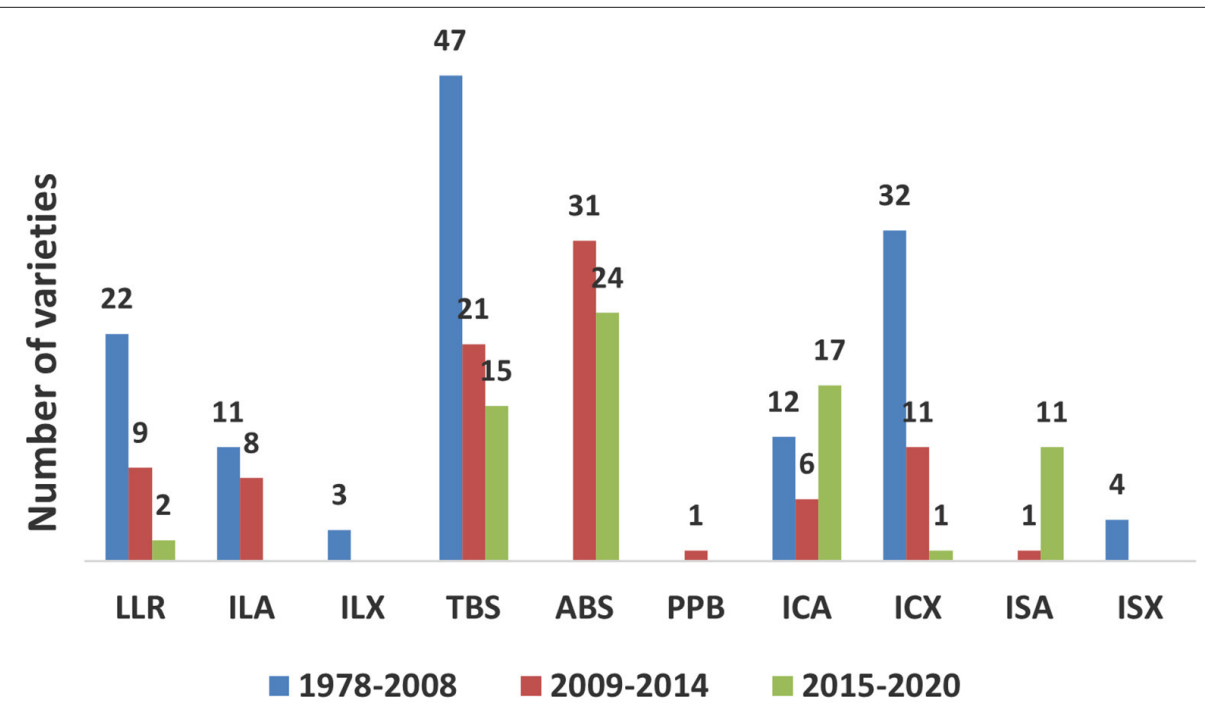

FIGURE 1 | Sweetpotato varieties released in sub-Saharan Africa during 2009 to 2020 as local landrace (LLR), introduced African landrace (ILA), introduced non-African landrace (ILX), bred in country using traditional breeding scheme (TBS), accelerated breeding scheme (ABS), participatory plant breeding (PPB), introduced clone from African breeding program (ICA), introduced clone from non-African breeding program (ICX), introduced seed from an African breeding program (ISA), or introduced seed from non-African breeding program (ISX).

The mean SPVD scores of the B80 $\times$ A50 offspring differed significantly from the $5 \mathrm{~B} \times 3 \mathrm{~A}$ offspring as indicated by a $t$-test of the transformed values. The SPVD frequency of genotypes with SPVD score below 3 increased from about $10 \%$ in the progeny of the original population $(80 \mathrm{~B} \times 50 \mathrm{~A})$ to $30 \%$ in the progeny of the eight SPVD-resistant parents $(5 B \times 3 A)$ (Table 6).

\section{Drought Tolerance} Mid-Season Drought Stress Under Field Conditions

Precipitation received during the life span of the drought trials was negligible and did not affect the mid-season drought stress treatment in 2015 seasons A and B (Figure 2). Season C established in 2016 received some precipitation during the 
TABLE 5 | Sweetpotato clones phenotyped for sweetpotato virus disease (SPVD) resistance at Namulonge, Uganda, and average scores.

\begin{tabular}{|c|c|c|c|c|c|c|c|c|c|c|c|c|}
\hline \multirow{2}{*}{$\begin{array}{l}\text { Clone } \\
\text { code }\end{array}$} & \multirow{2}{*}{$\begin{array}{l}\text { Family } \\
\text { number }\end{array}$} & \multicolumn{2}{|c|}{ Pedigree } & \multirow{2}{*}{$\begin{array}{l}\text { Flesh } \\
\text { color }\end{array}$} & \multirow{2}{*}{$\begin{array}{l}\text { Root } \\
\text { yield } \\
\text { (t/ha) }\end{array}$} & \multirow{2}{*}{$\begin{array}{l}\text { Vine } \\
\text { yield } \\
\text { (t/ha) }\end{array}$} & \multirow{2}{*}{$\begin{array}{c}\text { Biomass } \\
\text { yield (t/ha) }\end{array}$} & \multirow[t]{2}{*}{ Alter-naria } & \multirow{2}{*}{$\begin{array}{l}\text { SPVD } \\
\text { score }\end{array}$} & \multirow{2}{*}{$\begin{array}{l}\text { SPFMV }^{b} \\
(1 / \Delta C t)\end{array}$} & \multirow{2}{*}{$\begin{array}{l}\text { SPCSV } \\
(1 / \Delta C t)\end{array}$} & \multirow{2}{*}{$\begin{array}{l}\text { SPVD } \\
\text { resistance } \\
\text { phenotype }\end{array}$} \\
\hline & & Female & Male & & & & & & & & & \\
\hline 4.3 & CIP110005 & CIP107719.1 & CIP107751.7 & $\mathrm{O}$ & 5.1 & 8.5 & 13.6 & 3.3 & 5.3 & 0.556 & 1.011 & S \\
\hline 11.7 & CIP110021 & CIP107729.9 & CIP107719.1 & Y & 22.8 & 10.1 & 32.9 & 2.3 & 3.3 & 0.72 & 0.12 & $\mathrm{~T}$ \\
\hline 12.22 & CIP110022 & CIP107729.9 & CIP189123.2 & $\mathrm{O}$ & 6.6 & 12.1 & 18.7 & 3.3 & 6.0 & 0.19 & 0.11 & S \\
\hline 17.3 & CIP110035 & CIP189148.21 & CIP189151.3 & C & 6.1 & 6.2 & 12.3 & 2.7 & 3.0 & 0.053 & 0.067 & $\mathrm{R}$ \\
\hline 18.17 & CIP110036 & CIP189148.21 & CIP107751.7 & $\mathrm{O}$ & 3.3 & 6.8 & 10.1 & 2.7 & 5.0 & 0.665 & 0.13 & S \\
\hline 20.8 & CIP110045 & CIP420269 & CIP189151.3 & LO & 14.3 & 8.3 & 22.6 & 4.0 & 4.0 & 0.053 & 0.053 & $\mathrm{~T}$ \\
\hline 21.4 & CIP110046 & CIP420269 & CIP107751.7 & LO & 16.2 & 8.4 & 24.6 & 2.3 & 3.3 & 0.144 & 0.463 & $\mathrm{~T}$ \\
\hline 23.11 & CIP110077 & CIP189151.34 & CIP107780.7 & $\mathrm{O}$ & 19.9 & 9.3 & 29.2 & 2.3 & 2.3 & 0.273 & 0.162 & $\mathrm{~T}$ \\
\hline 24.7 & CIP110078 & CIP189151.34 & CIP107719.1 & LO & 5.4 & 14.7 & 20.2 & 2.3 & 2.7 & 0.053 & 0.053 & $\mathrm{R}$ \\
\hline 29.3 & CIP110100 & CIP107718.3 & CIP107733.5 & C & 7.0 & 7.9 & 14.9 & 2.3 & 5.3 & 0.052 & 0.349 & $S$ \\
\hline 29.6 & CIP110100 & CIP107718.3 & CIP107733.5 & Y & 5.6 & 8.3 & 13.9 & 3.3 & 5.3 & 0.583 & 0.187 & $S$ \\
\hline 34.6 & CIP110128 & CIP107707.6 & CIP107744.2 & $\mathrm{C}$ & 9.8 & 7.5 & 17.3 & 2.0 & 5.0 & 0.178 & 0.077 & S \\
\hline NASPOT 11 & & CIP441745 & $\mathrm{OP}$ & & 17.4 & 12.7 & 30.1 & 2.0 & 2.7 & 0.113 & 0.064 & $\mathrm{R}$ \\
\hline Mean & & & & & 10.7 & 9.3 & 20.0 & 2.7 & 4.1 & (0.052) & $(0.062)$ & \\
\hline $\mathrm{LSD}_{0.05}$ & & & & & 4.9 & 5.0 & 6.2 & 0.9 & 2.0 & & & \\
\hline CV (\%) & & & & & 27.3 & 32.1 & 18.6 & 20.5 & 29.8 & & & \\
\hline
\end{tabular}

a SPVD, sweetpotato virus disease; SPFMV, Sweet potato feathery mottle virus; SPCSV, Sweet potato chlorotic stunt virus; O, orange; Y, yellow; C, cream; LO, light orange.

${ }^{b} \Delta C t$, Delta Ct = [Ct gene test - Ct endogenous control]; (), negative control; LSD, least significant difference at 5\%; CV, coefficient of variation; Characterization based on symptoms,

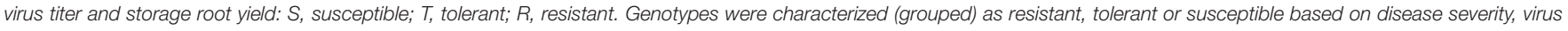

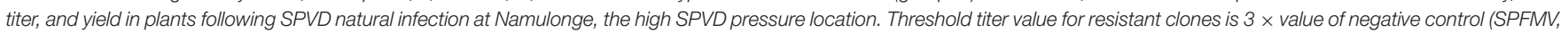
$0.052 \times 3=0.156$; SPCSV, $0.062 \times 3=0.0866$; resistant clones have values less $3 \times$ negative control and mild or no symptoms.

TABLE 6 | Comparison of frequency of resistant genotypes to sweetpotato virus disease (SPVD) in different sweetpotato breeding populations at Namulonge, Uganda.

\begin{tabular}{|c|c|c|c|}
\hline Cross and test crosses to improve SPVD resistance ${ }^{a}$ & Mean offspring log (SPVD)* & Mean offspring SPVD & $\begin{array}{c}\text { Percent frequency of resistant } \\
\text { genotypes (score } \leq 3 \text { ) }\end{array}$ \\
\hline B80 × A50 trial (5031 genotypes, year $2016-2017)$ & 1.42 & 4.4 & 13.3 \\
\hline Test cross 3A × 5B (999 genotypes, year 2018 - 2019) & 1.17 & 3.39 & 32.2 \\
\hline Difference & 0.24 & 1.01 & \\
\hline$P$-value & $<0.001$ & & \\
\hline 95\% Confidence interval & $0.23-0.27$ & & \\
\hline
\end{tabular}

\section{Earlier SPVD screening trials in 2010 (i) and 2011 (ii)}

NASPOT 11 (4 out 4,000 genotypes) (i) 0.075

NASPOT 7, 8, 90 and 100 [4 out of 70,279 genotypes (ii)] 0.006

${ }^{a}$ Two Ugandan populations, A with 50 genotypes (A50) used as male and B with 80 genotypes (B80) used as female; ${ }^{\star} T$-test (log transformed SPVD scores): $t=21.825, d f=1154.8$, $P<2.2 e-16$ (https://doi.org/10.21223/JTZY5W); i, ii Mwanga et al. (2009, 2011).

growth stages of the sweetpotato, but largely outside the planned drought stress period of between 70 and 90 DAP. Umbeluzi was a warm environment with maximum temperatures ranging between 20 and $40^{\circ} \mathrm{C}$ during all the three growing seasons.

\section{Drought Intensity Indices, Variation of Storage Root Yield and Other Traits}

Mean storage root yield over the three seasons was $36.40 \%$ lower in the mid-season drought stressed treatments of the optimum irrigation treatments using the drought intensity index calculated from the mean of all genotypes under both treatments
(Table 7). The mid-season drought stress reduced storage root yield by $24.7,41.6,42.0$, and $36.0 \%$ in the farmer variety group (Fv), international checks group (ICHECK), other countries group (OC), and released varieties and elite clone group (RC), respectively. A combined analysis across all the three seasons for each treatment showed that genotypic mean storage root yields ranged from 0 to $39.47 \mathrm{t} / \mathrm{ha}$ under optimum irrigation treatments and from 1.04 to $23.00 \mathrm{t} /$ ha under the drought stressed treatment imposed during the mid-season. The released varieties group had the highest average performance under the midseason drought stress treatments and the group of international 


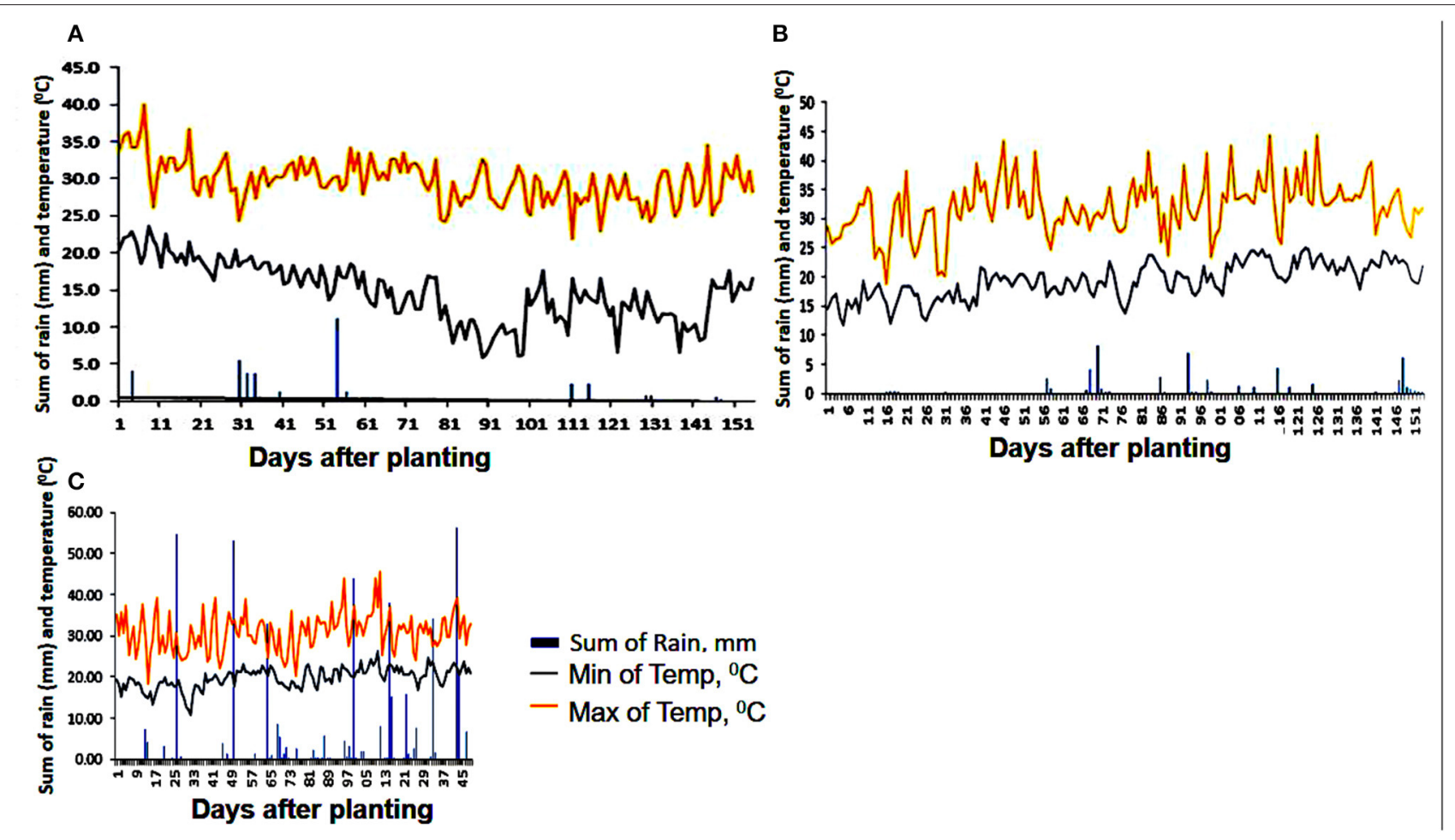

FIGURE 2 | Rainfall distribution (bars), as well as maximum and minimum temperatures (orange and gray lines, respectively) during the crop growth period of three separate experiments (A) planting date: 20 March 2015; harvest date: 20 August 2015, (B) planting date: 21 August 2015; harvest date: 20 January 2016, and (C) planting date: 05 September 2016; harvest time: 31 January 2017. The x-axis shows days after planting and the $y$-axes of the graphs show the sum of rainfall and temperatures, respectively.

checks had the least performance under similar conditions. The same trend was observed for plant length under the mid-season drought treatments. In addition, the international checks group had the least vine weight ( $\mathrm{t} / \mathrm{ha}$ ) under mid-season drought treatments. However, the international checks group had the highest vine internode length $(\mathrm{cm})$ under mid-season drought stress treatments.

The drought indices in Table 7 for storage root yield identified the following genotypes, Canassumana, Maphuta, Mwamazambane, Nwamonguane, Xiadla Xakau, and Xitsekele in the Fv group, 440203 in the OC group and Erica, Gloria, Lawrence, and Victoria in RC group as tolerant to the midseason drought stress imposed during the three seasons based on their low TOL $(<6)$ and SSI values $(\leq 0.3)$. In addition, Irene, Lourdes, Margarete, and Namanga in the RC group were also tolerant to the mid-season drought based on their low SSI values. When GMP index set for $>15$ t/ha was applied to the genotypes considered as tolerant to mid-season drought stress based on low TOL and SSI values, Maphuta, Mwamazambane, Canassumana (Fv group) and Irene, Lourdes, Margarete, and Namanga (RC group) were rated less sensitive to drought and with high productivity under both the optimum irrigation and mid-season drought stress treatments. The HI of these genotypes was $>45 \%$ under the mid-season drought stress treatments. Plant length was more than $100 \mathrm{~cm}$ for the Fv group and with moderate vine internode length of $<9 \mathrm{~cm}$. The vine internode length $(\mathrm{cm})$ of the identified drought tolerant varieties in the $\mathrm{RC}$ group was also moderate.

\section{Correlations Between Measured Traits}

Foliage yield had positive correlation with storage root yield under mid-season treatments (Table 8). HI and number of roots per plant had positive and high correlations with storage root yield obtained under both optimum irrigation and mid-season drought treatments. Morphological traits, vine internode length and plant length were positively and highly correlated under the two treatments.

\section{Breeding for High Iron and Zinc}

A total of 175 OFSP clones were identified by NIRS to contain the highest Fe and $\mathrm{Zn}$ contents and their subsequent analysis by the X-ray fluorescence technology (XRF) (Table 9). The Fe and Zn contents ranged from 2.05 to 3.40 and 0.76 to $2.10 \mathrm{mg} / 100 \mathrm{~g}$, DW by NIRS analysis, respectively. These 175 clones were then sent to CIP-Peru, where they were analyzed using the more accurate XRF technology for more precise Fe measurements. By $\mathrm{XRF}$ analysis, the Fe and $\mathrm{Zn}$ contents varied from 10.28 to 38.81 and 4.55 to $21.31 \mathrm{mg} / \mathrm{kg}$, DW, respectively. The top 30 OFSP clones in terms of Fe content were then sent to a laboratory in Australia, which analyzed the samples using inductively coupled plasma (ICP) (Table 10). The ICP technology has the capacity to detect contaminants in samples from other elements, such 
TABLE 7 | Variation of storage root yield (t/ha), vine weight $(\mathrm{t} / \mathrm{ha})$, vine internode length $(\mathrm{cm})$, plant length $(\mathrm{cm})$ and vine diameter $(\mathrm{mm})$ as well as drought tolerance indices, stress tolerance (TOL), geometric mean of productivity (GMP), stress susceptibility index (SSI) and harvest index (hi) in a subset of diverse sweetpotato genotypes evaluated under drought stress trials at Umbeluzi Research Station from 2015 to 2017.

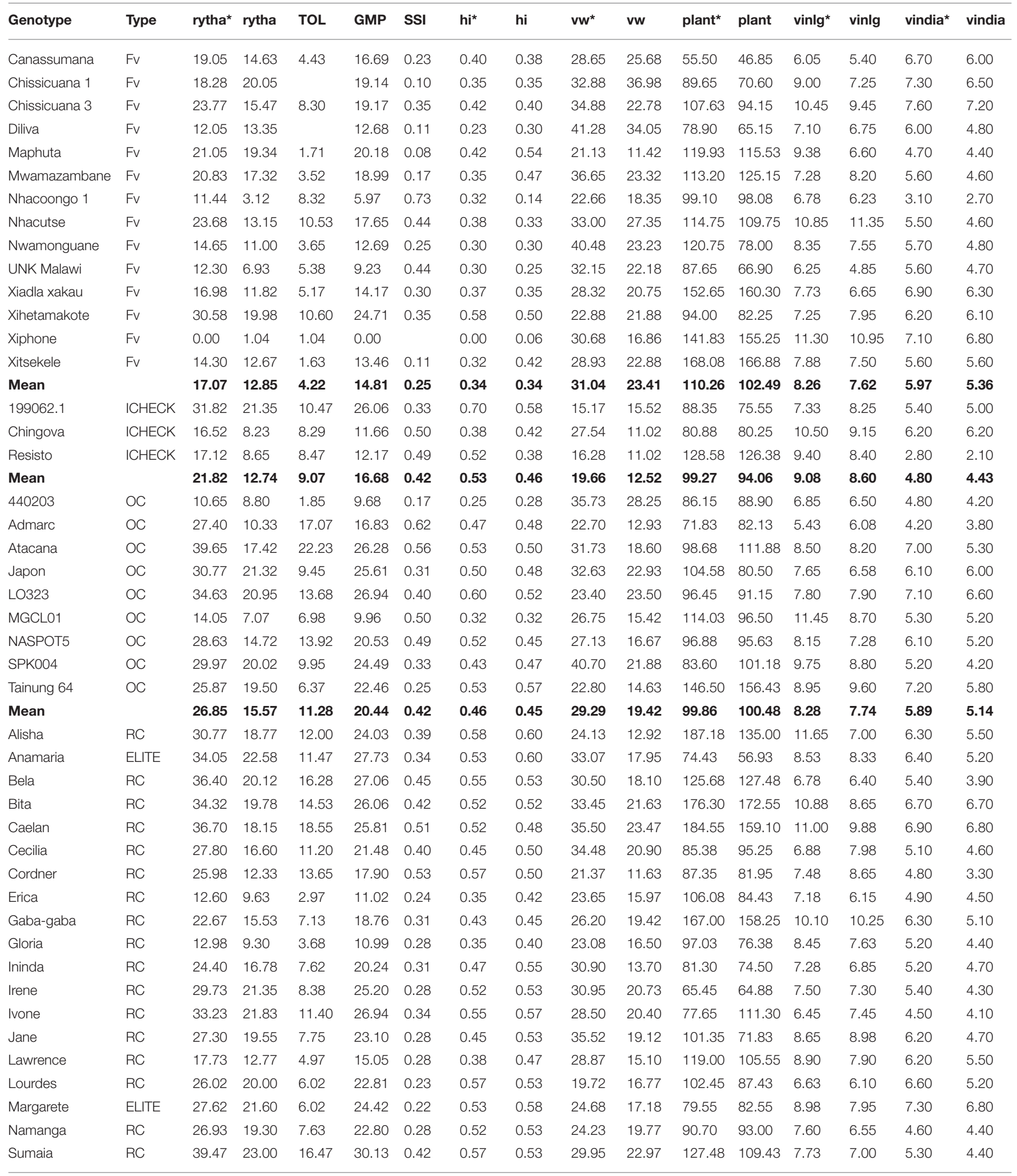


TABLE 7 | Continued

\begin{tabular}{|c|c|c|c|c|c|c|c|c|c|c|c|c|c|c|c|c|}
\hline Genotype & Type & rytha* & rytha & TOL & GMP & SSI & $\mathbf{h i}^{*}$ & hi & $\mathbf{v w}^{*}$ & vw & plant* & plant & vinlg* & vinlg & vindia* & vindia \\
\hline Tio Joe & $\mathrm{RC}$ & 25.38 & 13.42 & 11.97 & 18.45 & 0.47 & 0.45 & 0.52 & 30.60 & 14.68 & 200.13 & 128.20 & 14.23 & 10.78 & 3.60 & 2.60 \\
\hline Victoria & $\mathrm{RC}$ & 17.07 & 11.72 & 5.35 & 14.14 & 0.31 & 0.40 & 0.52 & 26.95 & 13.30 & 148.23 & 99.33 & 9.38 & 6.73 & 4.90 & 4.10 \\
\hline Mean & & 27.10 & 17.34 & 9.76 & 21.68 & 0.36 & 0.49 & 0.52 & 28.40 & 17.72 & 118.30 & 103.59 & 8.68 & 7.84 & 5.61 & 4.80 \\
\hline Grand mean & & 24.53 & 15.6 & 8.98 & 19.53 & 0.37 & 0.45 & 0.46 & 28.56 & 19 & 113.06 & 104.53 & 8.6 & 7.9 & 5.70 & 5.00 \\
\hline
\end{tabular}

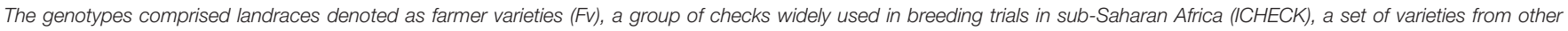

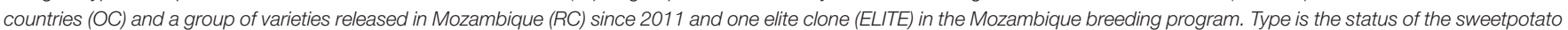

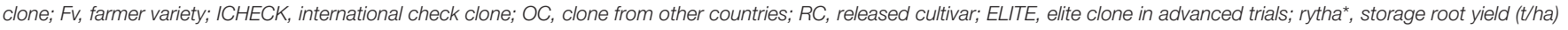

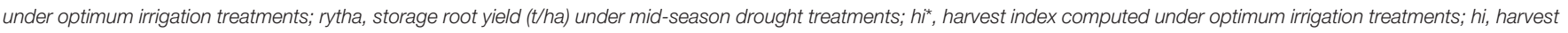

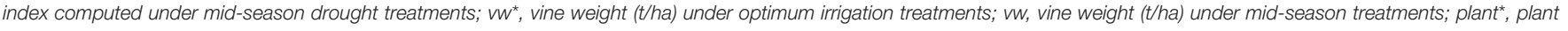

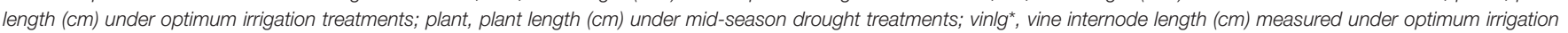

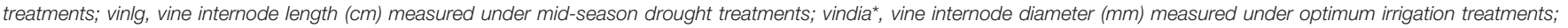
vindia, vine diameter $(\mathrm{mm})$ measured under mid-season drought treatments; bold values indicate means of each type of genotype and grand mean.

TABLE 8 | Correlation of traits measured in drought trials of sweetpotato under optimum irrigation and mid-season drought stress treatments at Umbeluzi Research Station from 2015 to 2017.

\begin{tabular}{|c|c|c|c|c|c|c|c|}
\hline & Stress regime & $\begin{array}{c}\text { Storage root } \\
\text { yield (t/ha) }\end{array}$ & $\begin{array}{c}\text { Foliage } \\
\text { yield (t/ha) }\end{array}$ & $\begin{array}{l}\text { Harvest } \\
\text { index }\end{array}$ & $\begin{array}{c}\text { Number of } \\
\text { roots per plant }\end{array}$ & $\begin{array}{l}\text { Plant length } \\
\text { (cm) }\end{array}$ & $\begin{array}{c}\text { Vine internode } \\
\text { length (cm) }\end{array}$ \\
\hline \multirow[t]{2}{*}{ Storage root yield (t/ha) } & Mid-season drought & 1.0 & 0.17 & 0.83 & 0.69 & -0.07 & -0.01 \\
\hline & Optimum irrigation & 1.0 & -0.01 & 0.86 & 0.50 & 0.01 & -0.04 \\
\hline \multirow[t]{2}{*}{ Foliage yield (t/ha) } & Mid-season drought & $0.17^{\star \star}$ & 1.0 & -0.31 & 0.005 & -0.13 & -0.06 \\
\hline & Optimum irrigation & $-0.01^{\star \star \star}$ & 1.0 & -0.43 & 0.06 & -0.01 & 0.11 \\
\hline \multirow[t]{2}{*}{ Harvest index } & Mid-season drought & $0.83^{\star \star \star}$ & $-0.31^{\star \star}$ & 1.0 & $0.69^{\star \star \star}$ & -0.02 & 0.01 \\
\hline & Optimum irrigation & $0.86^{\star \star \star}$ & $-0.43^{\star \star \star}$ & 1.0 & $0.53^{\star \star \star}$ & -0.03 & -0.15 \\
\hline \multirow[t]{2}{*}{ Number of roots per plant } & Mid-season drought & $0.69^{\star \star}$ & 0.005 & 0.69 & 1.0 & -0.09 & -0.06 \\
\hline & Optimum irrigation & $0.50^{\star}$ & 0.06 & 0.53 & 1.0 & 0.02 & -0.11 \\
\hline \multirow[t]{2}{*}{ Plant length (cm) } & Mid-season drought & -0.07 & -0.13 & -0.02 & -0.09 & 1.0 & 0.43 \\
\hline & Optimum irrigation & 0.01 & -0.01 & -0.03 & 0.02 & 1.0 & 0.65 \\
\hline \multirow[t]{2}{*}{ Vine internode length } & Mid-season drought & -0.01 & -0.06 & 0.01 & -0.06 & $0.43^{\star \star \star}$ & 1.0 \\
\hline & Optimum irrigation & -0.04 & 0.11 & -0.15 & -0.11 & $0.65^{\star \star \star}$ & 1.0 \\
\hline
\end{tabular}

All correlations marked with asterisk(s) are significant at ${ }^{\star} P \leq 0.05 ;{ }^{* \star} P \leq 0.01$; ${ }^{* \star *} P \leq 0.001$.

as aluminum. The Fe readings are invalid if contaminants are above designated cut-off points. One clone, MUSG15052-2, high in $\mathrm{Fe}$ content was identified to be free of contaminants and recommended for inclusion in a study of Fe bioavailability.

\section{QTL Mapping for $\beta$-Carotene, Iron, and Zinc}

The BT mapping population was evaluated for three biofortification traits in Ghana. Trait segregation was observed for all traits, with concentration ranges (in $\mathrm{mg} / 100 \mathrm{~g}, \mathrm{DW}$ ) of 0.00-39.37 for $\beta$-carotene, 1.35-2.96 for $\mathrm{Fe}$, and $0.70-1.76$ for $\mathrm{Zn}$. The heritability values $\left(H^{2}\right)$ were high for $\beta$-carotene (0.91-0.96) and moderate for $\mathrm{Fe}(0.74-0.83)$ and $\mathrm{Zn}(0.59-0.84)$ across trials, meaning that a significant portion of the phenotypic variance could be explained by genetic differences among progenies.

QTL mapping showed strong evidence of two QTL for each trait, with peaks located on the same linkage group (LG) regions across traits, one each on LG 3 and 12 (Table 11; Figure 3A). The QTL on LG 3 were more closely linked, with their 95\% support intervals mostly superimposed, whereas the support intervals for
QTL on LG 12 were only partially superimposed. On LG 12, QTL peaks for $\beta$-carotene and Fe were at $139.28 \sim 147.03 \mathrm{cM}$, whereas for $\mathrm{Zn}$ it was at $80.49 \mathrm{cM}$. From the QTL heritability values $\left(h_{Q T L}^{2}\right)$, we noticed that these two QTL were able to explain as much as 65.8 and $51.0 \%$ for $\beta$-carotene and $\mathrm{Fe}$, respectively, and $23.5 \%$ for $\mathrm{Zn}$.

The breakdown of QTL genotypic values allowed us to observe that some alleles contributed concomitantly to the trait means more than others. For example, the haplotype $d$ (from Beauregard) on LG 3, and $d$ (from Beauregard) and $l$ (from Tanzania) on LG 12 were the ones responsible for increasing $\beta$-carotene, $\mathrm{Fe}$, and $\mathrm{Zn}$ contents in the progenies with such alleles (Figure 3B). Pearson's pairwise correlations between phenotypic adjusted means were positive (0.67 $\beta$ carotene/Fe, $0.47 \beta$-carotene $/ \mathrm{Zn}$, and $0.86 \mathrm{Fe} / \mathrm{Zn})$ and highly significant $(P<0.001$; Figure $3 \mathrm{C})$. The co-located QTL as well as the allele with similar effects on the traits explain the high positive correlation, ranging from 0.60 ( $\beta$-carotene/Zn) to $0.90(\beta$-carotene $/ \mathrm{Fe})$, between QTL-based predicted means (Figure 3D). 
TABLE 9 | Sweetpotato clones with high iron and zinc contents determined by near-infrared spectroscopy in Mozambique and X-ray fluorescence in Lima, Peru, in 2016.

\begin{tabular}{|c|c|c|c|c|c|}
\hline \multirow[t]{2}{*}{ Clone name } & \multicolumn{3}{|c|}{ NIRS analysis - Mozambique } & \multicolumn{2}{|c|}{ XRF analysis - Lima, Peru } \\
\hline & DM (\%) & $\mathrm{Fe}(\mathrm{mg} / 100 \mathrm{~g}, \mathrm{DW})$ & $\mathrm{Zn}(\mathrm{mg} / 100 \mathrm{~g}, \mathrm{DW})$ & $\mathrm{Fe}(\mathrm{mg} / 100 \mathrm{~g}, \mathrm{DW})$ & $\mathrm{Zn}(\mathrm{mg} / 100 \mathrm{~g}, \mathrm{DW})$ \\
\hline \multicolumn{6}{|c|}{ TEN SUPERIOR GENOTYPES BY NIRS } \\
\hline MUSG15030-12 & 21 & 3.4 & 2.1 & 2.692 & 1.136 \\
\hline MUSG15029-19 & 24.1 & 3.2 & 1.9 & 2.033 & 1.141 \\
\hline MUSG15045-2 & 23.8 & 3.1 & 1.8 & 2.147 & 0.985 \\
\hline MUSG15099-17 & 22.8 & 2.9 & 1.4 & 2.286 & 0.89 \\
\hline MUSG15123-6 & 23.3 & 2.9 & 1.5 & 1.611 & 1.035 \\
\hline MUSG15139-7 & 30.5 & 2.9 & 1.7 & 2.184 & 0.645 \\
\hline MUSG15134-2 & 19.8 & 2.9 & 1.7 & 2.228 & 1.119 \\
\hline MUSG15117-17 & 20.6 & 2.8 & 1.5 & 2.865 & 0.909 \\
\hline MUSG15037-19 & 20.36 & 2.06 & 1.26 & 1.687 & 0.797 \\
\hline MUSG15120-7 & 24.96 & 2.06 & 1.29 & 1.515 & 1.005 \\
\hline MUSG15029-6 & 20.7 & 2.05 & 1.19 & 1.702 & 1.304 \\
\hline Mean & 22.6 & 2.45 & 1.44 & 1.928 & 0.885 \\
\hline Maximum & 30.78 & 3.4 & 2.1 & 3.881 & 2.131 \\
\hline Minimum & 17.4 & 2.05 & 0.76 & 1.028 & 0.455 \\
\hline
\end{tabular}

DM, dry matter \%; DW, dry weight; NIRS, near-infrared spectroscopy; XRF, X-ray fluorescence; bold values indicate maximum, minimum and mean analysis values based on 250 clones.

TABLE 10 | Inductively coupled plasma (ICP) analysis of top 30 orange-fleshed sweetpotato identified by X-ray fluorescence (XRF).

\begin{tabular}{|c|c|c|c|c|c|c|c|}
\hline Genotype & \multicolumn{5}{|c|}{ ICP - Australia } & \multicolumn{2}{|c|}{ XRF-CIP } \\
\hline \multicolumn{8}{|c|}{ TOP 10 CLONES BY XFR ANALYSIS } \\
\hline MUSG15052-2 & 4.4 & 0.8 & 0.1 & 0.005 & 0.008 & 3.881 & 0.842 \\
\hline MUSG15105-17 & 4.4 & 0.6 & 0.25 & 0.004 & 0.014 & 3.687 & 0.778 \\
\hline MUSG15057-6 & 4.2 & 1.0 & 0.68 & 0.007 & 0.024 & 3.629 & 1.248 \\
\hline MUSG15092-17 & 4.2 & 0.8 & 0.97 & 0.009 & 0.095 & 3.519 & 0.972 \\
\hline MUSG15111-18 & 4.1 & 0.9 & 0.2 & 0.004 & 0.066 & 3.510 & 1.160 \\
\hline MUSG15111-18 & 3.9 & 0.8 & 0.15 & 0.004 & 0.044 & 3.331 & 1.046 \\
\hline MUSG15117-17 & 3.6 & 0.8 & 0.08 & 0.007 & 0.017 & 2.865 & 0.909 \\
\hline MUSG15016-1 & 3.6 & 0.7 & 0.16 & 0.009 & 0.027 & 3.388 & 0.828 \\
\hline MUSG15018-3 & 2.7 & 0.6 & 0.09 & 0.003 & 0.037 & 2.502 & 0.752 \\
\hline MUSG15050-17 & 2.6 & 0.8 & 0.22 & 0.006 & 0.038 & 2.592 & 1.130 \\
\hline MUSG15052-3 & 2.6 & 0.6 & 0.13 & 0.006 & 0.012 & 2.614 & 0.870 \\
\hline MUSG15139-8 & 2.6 & 0.6 & 0.20 & 0.007 & 0.038 & 2.184 & 0.645 \\
\hline Mean & 3.241 & 0.768 & 0.287 & 0.006 & 0.042 & 2.906 & 1.013 \\
\hline
\end{tabular}

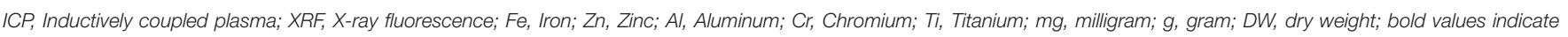
means of samples based on 30 clones. 
TABLE 11 | Quantitative trait loci (QTL) for $\beta$-carotene (BC), iron (Fe), and zinc (Zn) for the Beauregard $\times$ Tanzania mapping population.

\begin{tabular}{|c|c|c|c|c|c|c|c|c|}
\hline Trait & QTL & LG & \multicolumn{2}{|c|}{ Position } & \multicolumn{2}{|c|}{ Support interval } & $P$-value & $h_{\mathrm{QTL}}^{2}$ \\
\hline & 2 & 12 & 147.03 & $22,131,994$ & $130.24-162.05$ & $21,077,116-23,026,694$ & $<2.22 \mathrm{e}-16$ & 0.265 \\
\hline \multirow[t]{2}{*}{$\mathrm{Fe}$} & 1 & 3 & 36.14 & $2,994,719$ & $24.47-50.15$ & $1,867,420-3,836,016$ & $<2.22 \mathrm{e}-16$ & 0.320 \\
\hline & 2 & 12 & 139.28 & $21,560,646$ & $132.20-145.30$ & $21,177,221-21,951,557$ & $<2.22 \mathrm{e}-16$ & 0.190 \\
\hline
\end{tabular}

Each QTL peak is identified in its respective linkage group (LG) by its position in centiMorgans (CM) and the corresponding marker relative to the Ipomoea trifida reference genome in base pairs (bp). P-value is relative to the highest score statistics, and $h_{Q T L}^{2}$ is the QTL heritability.

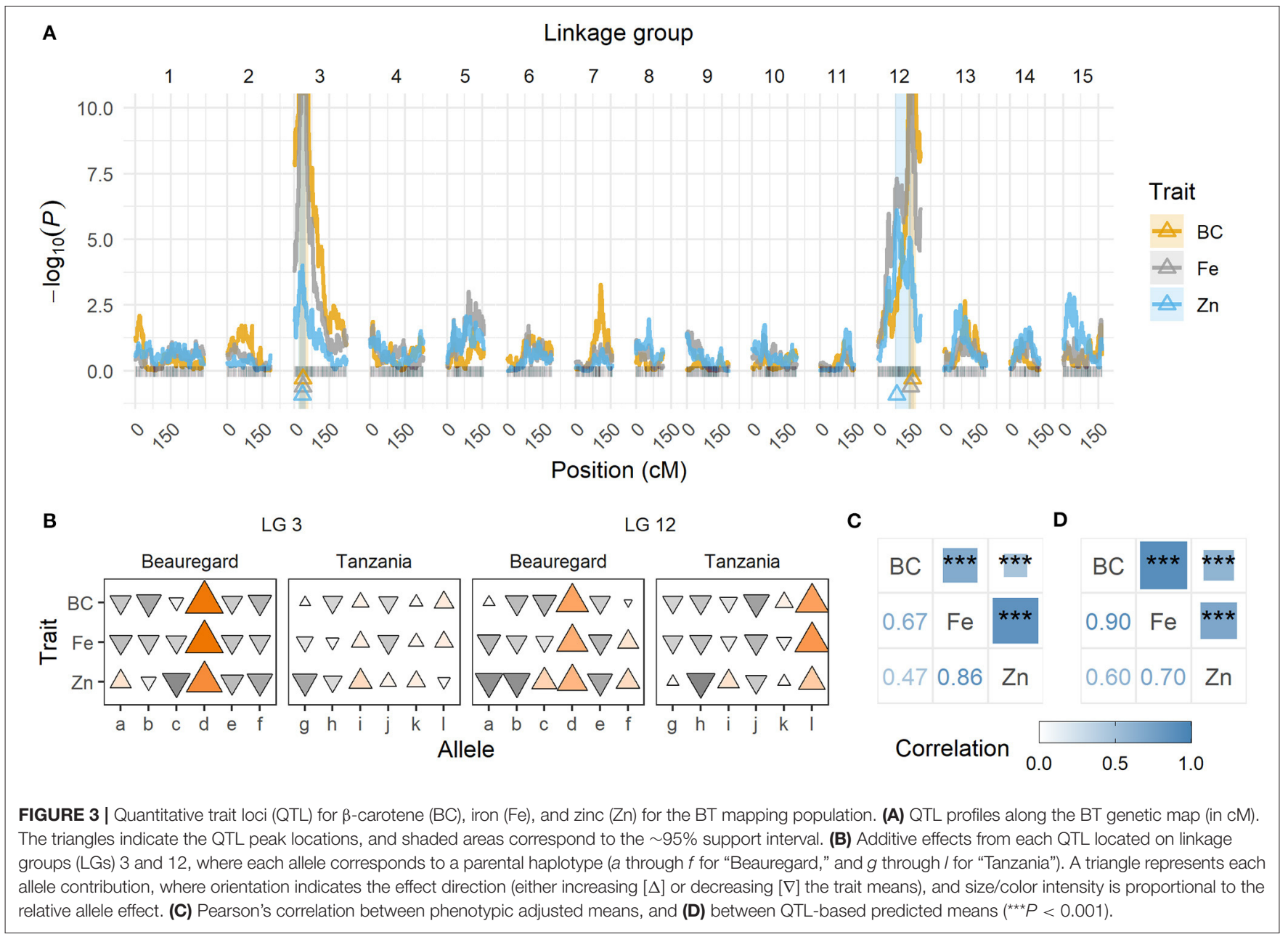

On developing digital tools for sweetpotato breeding, the collaborating teams developed a manual of procedures and tools, such as Field Book and SweetpotatoBase for electronic data capture for the evaluation and analysis of sweetpotato trials (crossing blocks, seedling nursery, observation, multilocation preliminary, advanced, and on-farm) providing standard methods and technology updates for the CIP Sweetpotato Support Platforms and the partners in SSA (Grüneberg et al., 2019).

\section{DISCUSSION}

\section{Population and Varietal Improvement and SPVD Resistance \\ Population Improvement and Variety Improvement Schemes}

The modified breeding procedures and sweetpotato improvement schemes adapted in SSA national programs led to African countries releasing biofortified adapted improved 
varieties in about four years instead of the traditional eight years (Table 4). This demonstrated progress requires continuous improvement to exploit heterosis (Grüneberg et al., 2005, 2015) combined with other desirable traits, such as continuous storage root formation and bulking (Bararyenya et al., 2020) weevil resistance, underground storability and long shelf life of storage roots (Low et al., 2009) as product profiles for different market segments are developed to improve genetic gains.

\section{SPVD Resistance}

Based on the data in Table 5, the clones can be grouped or categorized as: (1) susceptible, exhibiting severe SPVD symptoms with severe yield reduction and high virus titer (clones 4.3, 12.22, 18.17, 29.3, 29.6, 34.6); (2) tolerant, exhibiting severe SPVD symptoms, low virus titer (20.8) but giving high yield (above 10 $\mathrm{t} / \mathrm{ha}$ ), or mild or severe SPVD symptoms with high virus titer but giving high yield or mild or no symptoms and high virus titer but giving high yield (clone 23.11); (3) resistant, exhibiting mild or no SPVD symptoms and low virus titer (clones 17.3, 24.7, and the local check, NASPOT 11). Clone 20.8 had high mean Alternaria bataticola blight score (4.0) which might have impacted the response of the clone to SPVD, aggravating its reaction to the disease, resulting in a higher SPVD mean score. The best combination would be a clone with high yield, low or no SPVD symptoms and low virus titer, such as NASPOT 11 especially in the farming system. In search of resistance, SPVD resistant clones with low yield and tolerant clones can be used in crossing programs with caution, studying the heritability, resistance and yield in the progeny at each crossing step to obtain promising parents to increase the frequency of SPVD resistance in the progeny. Accession 23.11 would be promising for high $\beta$-carotene because of its orange flesh color and because of its apparent resistance to Alternaria stem blight which is as good as that of NASPOT 11 which has high field resistance to the disease (Table 5). It would, however, be used in crossing aiming at selecting resistant genotypes in the progeny.

Except for accession 24.7 and the check clone, all the evaluated genotypes can be eliminated on the basis of symptom expression (SPVD and Alternaria blight score of 3.5 or more) or high virus titer accumulation (three times or more the value of the negative control) or both. A combination of field evaluation based on symptom expression and use of qRT-PCR enables an accurate discrimination of SPVD resistance status (susceptible, tolerant, and resistant) among sweetpotato clones. Other procedures able to measure or use a proxy for virus titer, such as quantitative enzyme-linked immunosorbent assay (ELISA) can be used instead of qRT-PCR, especially if they are cheaper. These results concur with the review by Clark et al. (2012).

Although 24.7 had very low storage root and moderate biomass yields, it exhibited low SPVD symptom expression and low virus titer accumulation; therefore, it could be considered to be a parental source of resistance for SPFMV and SPCSV. The 12 accessions had been in the field for only three seasons, whereas the check, NASPOT 11 also known as Tomulabula, had been in the field for more than 10 years, so comparison of the test clones with NASPOT 11 is not a level field for comparison. Molecular markers for SPVD resistance and some of the genes differentially expressed in resistant cultivars in response to infection have been identified by other workers; their validation and application in sweetpotato breeding should enable more efficient selection of resistant genotypes in the future (Clark et al., 2012). The procedure used at Namulonge enables selection of SPVD resistant clones with combination of other desirable traits, such as $\beta$-carotene, adequate dry matter content, biomass yield, and taste. Breeding populations generated from the population improvement scheme at the sweetpotato support platform in Uganda and SPVD resistant OFSP released in Uganda and screened in other SSA countries have led to release of OFSP varieties in several countries, Madagascar, Mozambique, Rwanda, Burundi, Tanzania, and Ethiopia. The national programs have released OFSP varieties following the developed procedure (Table 4).

\section{Drought Tolerance}

The full genetic potential of sweetpotato is not realized in arid and semi-arid areas due to low available soil moisture which can hardly support plant growth and later on storage root production. An average storage root yield of between 6 and $10 \mathrm{t} / \mathrm{ha}$ has been reported in farmers' fields across SSA due to mainly drought stress and constraints on seed availability and accessibility (Low et al., 2020). A grand storage root yield mean of $17.34 \mathrm{t} / \mathrm{ha}$ was realized under mid-season drought stress treatments imposed in the current study representing a $36.4 \%$ yield loss compared to optimum irrigation treatments across the three seasons (Table 7). Yield is the final trait used to assess drought tolerance of genotypes (Blum, 2011). The mid-season drought stress treatments represent sweetpotato growing regions in southern Mozambique and some parts of Tete Province which account for $40 \%$ of the farming families in Mozambique. The optimum irrigation treatments represent the central and northern parts of Mozambique which receive adequate rainfall for sweetpotato production. These target population environments are also found in other countries in Southern Africa since the inter-tropical convergence zone influences rainfall and rainfall patterns in this region.

Prediction on drought occurrence and severity is difficult. In the current study, the trial planted from September 2016 to January 2017 received some rainfall during the growing season while it never rained in the preceding trial planted from August 2015 to December 2015. This complexity of drought conditions was described by Amede et al. (2004).

The combined use of drought indices, SSI, TOL, and GMP to identify drought tolerant genotypes as well as genotypes with high productivity under both optimum irrigation and drought stressed environment assures breeding progress in marginal areas. Maphuta, Mwamazambane, Canassumana (Fv group) and Irene, Lourdes, Margarete, and Namanga (RC group) were identified as genotypes less sensitive to mid-season drought and with high productivity, higher than $15 \mathrm{t} / \mathrm{ha}$ under both the optimum irrigation and mid-season drought stress treatments. Alvaro et al. (2017) identified Irene and Victoria as early maturing varieties requiring between 90 and 120 days to mature. Victoria had GMP of $14.14 \mathrm{t} / \mathrm{ha}$ (slightly lower than benchmark of 
$15 \mathrm{t} / \mathrm{ha}$ ) and low TOL (5.35), SSI (0.31), and HI under midseason drought treatment of $52 \%$. Victoria is a common parent in crossing blocks established in Mozambique. Irene has been released in several countries in SSA and there are efforts to release it in the Middle East and Asia (Low et al., 2020). Earliness is one of the mechanisms of escaping terminal drought normally experienced at the storage root bulking phase between 9 and 17 weeks after planting. Drought escape is defined as the ability of a plant to complete its life cycle before severe soil and plant water deficits occur (Amede et al., 2004). The mechanism involves quick crop establishment, early root initiation and maturity. Drought escape is desirable and is useful in sweetpotato grown in semi-arid and arid areas. In addition to escaping drought, early maturing clones also escape diseases and pests which are associated with terminal drought. A hybrid population with a maturity period of 90 days was developed in Lima, Peru, targeting terminal/late season drought (Grüneberg et al., 2015). Maphuta was also reported as drought tolerant in South Africa (Laurie et al., 2015a).

The clones in the Fv group exhibited strong morphological characters desirable under arid and semi-arid environments. Both plant length and vine internode length contribute to vine vigor. In the case of Mwamazambane and Maphuta, the vines were long, more than $100 \mathrm{~cm}$ with moderate vine internode length and diameter. Sweetpotato propagation is mainly through vines which start to lose water once they are cut. Vines with a diameter of more than $4 \mathrm{~mm}$ are better adapted to early season drought, from planting until good establishment and for terminal drought as they are good in remobilization of assimilates to storage roots once a drought signal is perceived (Andrade et al., 2017; Low et al., 2020). In addition, thick vines are associated with high crop vigor from establishment until maturity which is associated with improved performance under drought conditions. Early crop vigor/early rapid growth or early development of above ground biomass allows early resource acquisition and reduced water evaporation from the soil (Abobatta, 2019).

Another trait for consideration when breeding for drought prone areas is the HI. HI is highly correlated with storage root yield under drought stress conditions and reflects the relationship between crop phenology and pattern of water use (Passioura, 1977). The HI for Maphuta, Mwamazambane, Canassumana (Fv group) and Irene, Lourdes, Margarete, and Namanga (RC group) is above $45 \%$ under the mid-season drought stress treatments (Table 7). This is an indication of the ability to remobilize assimilates from leaves and vines to storage roots during the period of high drought stress. Water use efficiency (WUE) is a prominent drought avoidance mechanism (Passioura, 1977). Extracted water is used efficiently toward producing high storage root yield under drought conditions (Ravi et al., 2011). Transpiration efficiency has been estimated through proxy traits, such as the SPAD chlorophyll meter reading, specific leaf area and carbon isotope discrimination ratio $\left(\delta^{13} \mathrm{C}\right)$ (Ravi et al., 2011). Recently, aerial vehicles to estimate canopy temperature were deployed in drought trials in Mozambique (Low et al., 2020). In addition, $\mathrm{N}$ and $\mathrm{C}$ isotope discrimination and SPAD chlorophyll meter reading were measured in the same trials.

\section{High Iron and Zinc Germplasm}

The NIRS technology is robust, faster and a cheaper way of identifying clones rich in Fe and $\mathrm{Zn}$ especially at early breeding stages where more than 5,000 clones must be analyzed for their nutrient contents in breeding programs. The standard operating procedures for nutrient analysis were developed (Porras et al., 2014) and well-adapted in Mozambique. To date, the first Fe bioavailability study in sweetpotato carried out in Malawi in 2019 is the direct evidence demonstrating the usefulness of the developed standard operating procedures for quality analysis. MUSG15052-2 (OFSP) bred in Mozambique had high Fe levels of $4.4 \mathrm{mg} / 100 \mathrm{~g}$, DW (ICP method of analysis) was subjected to Fe bioavailability studies in Malawi in 2019 led by ETH-Zurich and the College of Medicine in Malawi. The work on bioavailability of Fe has been published elsewhere (Laryea et al., 2018; Jongstra et al., 2020).

\section{QTL Mapping for $\beta$-Carotene, Iron, and Zinc}

We took advantage of NIRS-based $\beta$-carotene, Fe, and $\mathrm{Zn}$ measurements in a sweetpotato mapping population to study the genetic architecture of these traits. Both phenotypic heritability and pairwise correlation estimates ranged from moderate to high (Figure 3C) and were in accordance with previous studies (Courtney et al., 2008; Tumwegamire et al., 2011). A relatively simple genetic architecture was already evident for $\beta$-carotene content from data collected in Peru for the same BT population (Gemenet et al., 2020a). In that previous case, the two major QTL on LGs 3 and 12 explained $79.2 \%$ of the total variance, which was similar to what we found for data collected in Ghana $(65.8 \%$; Table 11). Our QTL were just $\sim 1 \mathrm{cM}$ away from those previously mapped (Gemenet et al., 2020a), suggesting that these QTL are likely stable and consistent across environments.

The variation for both $\mathrm{Fe}$ and $\mathrm{Zn}$ contents in the BT mapping population also appeared to be controlled by at least two major QTL, one on each LGs 3 and 12, close to those identified for $\beta$ carotene (Figure 3A). These QTL explained more of the variation for $\mathrm{Fe}(51.0 \%)$ than for $\mathrm{Zn}(23.5 \%)$. This could be due to two main factors. First, $\mathrm{Zn}$ seems to be influenced by additional minor QTL that have gone undetected. Second, parental allele effects for zinc were not as contrasting as those for Fe. In fact, major QTL allele effects ( $d$ on LG 3 and $d / l$ on LG 12) for $\beta$-carotene and $\mathrm{Fe}$ were relatively larger than those for $\mathrm{Zn}$ (Figure 3B). In addition to differences in QTL peak positions, the contrasts among allele effects also explains how QTL-based predicted means from $\beta$-carotene and iron were relatively more correlated $(0.90)$ than those between zinc and $\beta$-carotene $(0.60)$ or iron (0.70; Figure 3D).

Overall, these analyses exemplified not only the complete pipeline for dissecting the genetic architecture of a trait in sweetpotato, but also evidenced the potential of the genomic tools recently developed for autopolyploid species in supporting breeding decisions. In this case, $\beta$-carotene, $\mathrm{Fe}$, and $\mathrm{Zn}$ were found to share common genetic loci controlling their variations. This explains the observed correlation levels and provides genetic basis to improve more than one trait concurrently. These loci 
can be investigated further for putative genes and markers linked to haplotypes of interest for marker-assisted selection, or for leveraging QTL-informed genomic prediction models (Gemenet et al., 2020b). However, these strategies need to be validated in populations with broader genetic bases. The linkage and QTL mapping methods used here can be expanded for in-depth genetic studies of more complicated designs, such as multiparental crosses, typically used in sweetpotato breeding programs to help increase their genetic gains.

The developed procedures and tools are continuously being refined in response to: the needs of sweetpotato breeders, producers and consumers; and advances in breeding knowledge, tools and techniques. Good progress has been made in developing procedures and forms for the design of trials, and collection, archiving and analysis of data, such as CloneSelector, or the integrated electronic tools, such as the Highly Interactive Data Analysis Platform for Breeding (HIDAP) and SweetpotatoBase (https://sweetpotatobase.org/). However, their use at the support platforms and breeding programs in the SSA countries depended on available resources (such as trained scientists and technicians, equipment and funds); hence, in general, there are more activities at the support platform countries than the other SSA countries as is reflected in the release of sweetpotato varieties by the different countries (Table 4 ).

\section{Final Considerations Way Forward}

Whilst yield is the critical component for evaluation of drought tolerance in many row crops, additional traits, such as vine survival which drives the seed system in sweetpotato need consideration and incorporation into breeding programs. A combined use of drought indices in breeding programs allows accurate identification of genotypes tolerant to drought conditions and with high productivity in both optimum and drought stressed environments. Sweetpotato breeding programs also need to continue with the selection for early maturing clones. Drought escape is one of the low hanging fruits of drought tolerance mechanisms and can be combined with continuous improvement in the phenotyping procedures. However, breeders need to recognize that if harvested early, such varieties will need to be capable of storing out-of-ground and issues regarding planting material availability in unimodal growing areas may arise. Good and accurate phenotyping is the key to success of a breeding program by assuring precise selection accuracy and accurate heritability estimation. It is critical to understand that heritability of traits can be used as a selection criterion. Modifications to the breeding standard operating procedures were implemented (Grüneberg and Swanckaert, 2019; Grüneberg et al., 2019) and currently on-going to include robust statistical designs, best linear unbiased predictions instead of least square mean estimates, optimization of multi-stage selection in later breeding stages and use of linear mixed models. Later breeding stages currently use augmented p-rep designs at the first step of selection and row column designs at the second step of selection. Precise estimation of experimental error (Singh et al., 2003) and relying on the magnitude of heritability of a trait
(Ceccarelli, 1994) ensures good breeding progress for drought prone environments. Soil moisture measurements, soil nutrient content, water applied, temperature, humidity, and rainfall are measured precisely on drought trials. In Mozambique, automated weather stations were installed in fields where drought trials were evaluated and tensiometers were laid in drought trials.

In southern Africa, the period between two rainy seasons can extend from 6 to 8 months posing a great challenge in conservation of sweetpotato for the next planting season (Makunde et al., 2018). Vine survival, defined as the ability to sprout by small unmarketable storage roots before the rainy season, is a key survival mechanism between prolonged dry spells in southern Africa. The small unmarketable storage roots will be in sand storage at the farmers' homesteads during the prolonged dry period. The ability to store for more than 5 months and sprout thereafter should be assessed in cultivar development programs in dry regions (Low et al., 2020).

Biofortification of sweetpotato with $\mathrm{Fe}$ and $\mathrm{Zn}$ is possible through conventional breeding. The identification of clones rich in the two micronutrients can be achieved through following the use of the NIRS technology (Porras et al., 2014) in the early phases of evaluation and in the final stages of ICP analysis for concurrent confirmation of lack of soil contaminants by validating that the levels of chromium and other substances found in soil are at acceptable levels.

The next steps include sharing of the clones developed under the high iron program in Lima with the program in Mozambique and Uganda for clone evaluation and integration in the SSA national breeding programs and possible variety release. Other areas which need consideration, include utilizing purple-fleshed sweetpotato in breeding programs, attracting the private sector into sweetpotato breeding and seed production, and combining elite crosses with in-vitro germination and later with genomic selection with greater focus on consumer segments. Exchange of germplasm among the sub-regional support platforms and the national programs will enable the use of genotypes with high content of $\mathrm{Fe}, \mathrm{Zn}$, and $\beta$-carotene, with high resistance to SPVD and are tolerant to drought in their breeding programs. The programs would target higher genetic gains for the different combinations of the most important traits. Continuing with breeding for high $\mathrm{Fe}$ and $\mathrm{Zn}$ in hybrid populations applying reciprocal recurrent selection methods in improving parents in crossing blocks and cultivar development and release will add to the pool of available biofortified crops in the farming systems of SSA to alleviate micronutrient deficiencies. Conducting bioavailability studies for $\mathrm{Zn}$ would enrich knowledge on how these micronutrients are absorbed and retained in the human body.

\section{Lessons Learned}

All the teams working on the different challenges in the farming systems, quality breeding, drought tolerance breeding and virus resistance breeding have a common aim of contributing to increasing genetic gains in farmers' fields and sustaining or enhancing positively the impact on livelihoods. The different teams working together in developing standard operating 
procedures for data recording and data management in sweetpotato breeding activities improved their efficiency in their activities, such as phenotyping, crossing, near infrared reflectance spectroscopy quality assessment, germplasm management and DNA sample management. While the teams had these similarities in operation, they had differences in focus based on sub-region; those in East and Central Africa focusing on developing virus resistance, Southern Africa focusing on drought tolerance and in West Africa on dry matter and low sweetness. There are lessons to draw from this collaborative experience.

The main lessons learned during the breeding process by CIP and the national sweetpotato breeding program partners are highlighted below. The accelerated breeding scheme works well for sweetpotato and enabled the national programs with limited short-term grants (3 years), from Alliance for a Green Revolution in Africa (AGRA) to make significant progress in responding to malnutrition, food security, and adaptation to climate change challenges. Although a lot of botanical seed from population development programs was distributed, only three countries released 11 varieties selected from seed provided by the Ugandan population development program; five by Madagascar, three by Kenya, and three by Malawi. In contrast, when superior advanced clones or released varieties are sent to different countries as pathogen-tested cuttings, evaluations and uptake are faster. Several countries with minimal resources to have crossing blocks or desiring specific traits released varieties bred in other SSA countries, including Ivory Coast, Madagascar, Rwanda, and Burundi. Given that the implementation of the heterosis breeding scheme is more expensive than the accelerated breeding scheme, and AGRA stopped supporting national breeding efforts, national programs will most likely rely more heavily on selecting from varieties developed in other SSA countries or from seed from the population development platforms in the future. Having a more refined understanding of target populations of environments is needed and should help guide future breeding investments.

Field screening of sweetpotato germplasm for resistance to SPVD, commonly based on symptom severity and incidence of plants infected with the disease following natural infection, is problematic because vector populations fluctuate over seasons (for example, some plants may escape infection and might be considered resistant). Making significant progress for SPVD resistance and yield in the hot spot at Namulonge in Uganda necessitated using a combination of techniques (such as gene pool separation using simple sequence repeat markers, discrimination of disease-resistant and -tolerant genotypes, elimination of poor progenitors for SPVD resistance, selecting parents in a recurrent selection scheme based on best linear unbiased predictions, general combining ability, parents of elite crossings, best performing parents, and special consideration for $\beta$-carotene content). From populations of 130 parents (50 population $\mathrm{A}$ and 80 population $\mathrm{B}$ ), the base set of parents (20 genotypes from each population A and B) selected in 2019 to start the first cycle of recurrent selection, a heterosis exploiting breeding scheme in sweetpotato will enable a yield jump in a population with high SPVD resistance.
"Perfect" varieties are unknown. However, with experience and understanding of the improved varieties being widely adopted, the list of essential traits is expanding, with implications for breeding programs. The ability to establish easily and a good multiplication rate are priority essential traits for vine multipliers. Further, perishability of sweetpotato, both in-ground and postharvest, is a significant constraint yet to be addressed through systematic breeding efforts. In drought-prone areas, the ability of storage roots of a variety to sprout after a prolonged dry period is required for sustaining smallholder systems. In agroecologies where sweetpotato weevil pressure is not severe and sweetpotato is cultivated as a perennial crop, genotypes with continuous storage formation and bulking are preferred among small scale farmers. Noticeably, apart from good agronomic and adaptation traits, cooking profiles most desired by consumers are critical for wider adoption of a variety and gender differences in traits need to be considered.

It takes time, about 5 years to develop tools, such as SweetpotatoBase (https://sweetpotatobase.org/) for data collection, management, and analysis, especially when different institutions are involved, and tool developers do not work on the tool development full-time. Existing functioning tools should be supported until new tools truly are ready for use. Incountry training of national program technicians and breeders is required for significant use each time a new more efficient toolset is developed.

The idea of exploiting heterosis in a vegetatively propagated crop was initiated by the International Potato Center in Peru and took 10 years to test and validate in Mozambique, Uganda, Ghana and other national programs. This new breeding strategy emerging out of this work has the potential to enhance the rates of genetic gain for many traits, such as storage root yield, number of commercial roots, virus resistance, and iron status. It is therefore, essential for longer term, consistent support to test worthy ideas.

\section{DATA AVAILABILITY STATEMENT}

The datasets presented in this study can be found in online repositories. The names of the repository/repositories and accession number(s) can be found at: https://doi.org/10.21223/JTZY5W.

\section{AUTHOR CONTRIBUTIONS}

RM designed the SPVD trials and piloted regional sweetpotato breeding trial protocols for SSA and reviewed the manuscript. JS analyzed data from SPVD and breeding experiments and reviewed the manuscript. GS conducted the phenotypic and QTL analyses, wrote the related sections, and reviewed the manuscript for quality control. MA, GM, and SL designed the mineral nutrition and drought tolerance experiments and piloted regional sweetpotato breeding trial protocols. WG conceived and designed all the piloted regional sweetpotato breeding trial protocols, heterosis exploiting breeding scheme, and developed the BT population. JK designed the real time PCR primers for SPFMV and SPCSV and edited the relevant sections. MD 
analyzed the DNA data for the two sweetpotato populations in Uganda for improvement to exploit heterosis exploiting breeding scheme. BD, EC, GY, RS, OU, MA, BY, DC, BO, and DG designed and piloted the regional sweetpotato breeding trial protocols and the Beauregard $\times$ Tanzania study for West Africa and Uganda. KM, MC, and SK designed and conducted the national breeding trials for the accelerated breeding scheme in Tanzania, Zambia, and Burkina Faso. GY, HC, and JL provided the insights in drafting and reviewing the manuscript and overseeing BMGF funded research project management. JL coordinated breeding progress and reviewed data analysis as manager of the SASHA project, and reviewed the manuscript. All authors contributed to the article and approved the submitted version.

\section{FUNDING}

The breeding work at the Sweetpotato Support Platforms in Ghana, Mozambique, and Uganda was part of the Sweetpotato Action for Security and Health in Africa (SASHA) and the Sweetpotato Genetic Advances and Innovative Seed Systems (SweetGAINS) projects. BT mapping population related work was conducted as part of the Genomics Tools for Sweetpotato

\section{REFERENCES}

Abobatta, W. F. (2019). Drought adaptive mechanisms of plants - a review. Adv. Agric. Environ. Sci. Open Access 2, 42-45. doi: 10.30881/aaeoa.00021

Alston, J. M., Pardey, P. G., and Rao, X. (2020). The Payoff to Investing in CGIAR research. Twin Cities. Available online at: https://supportagresearch.org/assets/ pdf/Payoff_to_Investing_in_CGIAR_Research_final_October_2020.pdf

Alvaro, A., Andrade, M. I., Makunde, G. S., Dango, F., Idowu, O., and Grüneberg, W. (2017). Yield, nutritional quality and stability of orange-fleshed sweetpotato cultivars successively later harvesting periods in Mozambique. Open Agric. 2, 464-468. doi: 10.1515/opag-2017-0050

Amede, T., Kimaní, P., Ronno, W., Lunze, L., and Mbikay, N. (2004). Coping With Drought: Strategies to Improve Genetic Adaptation of Cornrnon Bean to Drought-Prone Regions of Africa. International Centre for Tropical Agriculture (Cali: CIAT).

Andrade, M. I., Naico, A., Ricardo, J., Eyzaguirre, R., Makunde, G. S., Ortiz, R., et al. (2016). Genotype $\times$ environment interaction and selection for drought adaptation in sweetpotato (Ipomoea batatas [L.] Lam.) in Mozambique. Euphytica 209, 261-280. doi: 10.1007/s10681-016-1684-4

Andrade, M. I., Ricard, J., Naico, A., Alvaro, A., Makunde, G. S., Low, J., et al. (2017). Release of orange-fleshed sweetpotato (Ipomoea batatas [L.] Lam.) cultivars in Mozambique through an accelerated breeding scheme. J. Agric. Sci. 155, 919-929. doi: 10.1017/S002185961600099X

Aritua, V., Alicai, T., Adipala, E., Carey, E. E., and Gibson, R. W. (1998). Aspects of resistance to sweet potato virus disease in sweet potato. Ann. Appl. Biol. 132, 387-398. doi: 10.1111/j.1744-7348.1998.tb05216.x

Bararyenya, A., Olukolu, B. A., Tukamuhabwa, P., Grüneberg, W. J., Ekaya, W., Low, J., et al. (2020). Genome-wide association study identified candidate genes controlling continuous storage root formation and bulking in hexaploid sweetpotato. BMC Plant Biol. 20:3. doi: 10.1186/s12870-019-2217-9

Barrett, C. B., and Bevis, L. E. M. (2015). "The micronutrient deficiencies challenge in African food systems," in The Fight Against Hunger and Malnutrition, ed D. E. Sahn (Oxford University Press), 61-88. doi: 10.1093/acprof:oso/9780198733201.003.0004

Belesova, K., Agabiirwe, C. N., Zou, M., Phalkey, R., and Wilkinson, P. (2019). Drought exposure as a risk factor for child undernutrition in low- and middle-income countries: a systematic review and assessment
Improvement (GT4SP). The three projects, SASHA, GT4SP and SweetGAINS were funded by the Bill and Melinda Gates Foundation [OPP1019987, OPP1052983, OPP1213329]. Countries participating in sweetpotato breeding activities were supported directly or indirectly by their national governments, and the Alliance for a Green Revolution in Africa (AGRA) gave breeding grants to nine countries, Burkina Faso, Kenya, Malawi, Mozambique, Nigeria, Rwanda, Tanzania, Uganda, and Zambia. The Centre for International Migration and Development (CIM) (a joint operation of GIZ and the German Federal Employment Agency on behalf of the German federal government) supported staff at CIP.

\section{ACKNOWLEDGMENTS}

This research was conducted under the auspices of the CGIAR Research Program on Roots, Tubers, and Bananas and supported by CGIAR Trust Fund contributors (https://www.cgiar.org/ research/). The authors would like to thank the strong and consistent support for sweetpotato breeding innovation from Jim Lorenzen and Lawrence Kent at the Bill and Melinda Gates Foundation. of empirical evidence. Environ. Int. 131:104973. doi: 10.1016/j.envint.2019. 104973

Blum, A. (2011). "Drought Resistance and Its Improvement," in Plant Breeding for Water-Limited Environments, eds H. T. Nguyen and A. Blum (New York, NY: Marcel Dekker, Inc), 53-152. doi: 10.1007/978-1-4419-7491-4_3

Bouis, H., Low, J., and Zeigler, R. (2019). "Delivering biofortified crops in developing countries," in Sustaining Global Food Security: The Nexus of Science and Policy, ed R. S. Zeigler (Clayton South, VIC: CSIRO), 82-96.

Ceccarelli, S. (1994). Specific adaptation and breeding for marginal conditions. Euphytica 77, 205-219. doi: 10.1007/BF02262633

Clark, C. A., Davis, J. A., Abad, J. A., Cuellar, W. J., Fuentes, S., Kreuze, J. F., et al. (2012). Sweetpotato viruses: 15 years of progress on understanding and managing complex diseases. Plant Dis. 96, 168-185. doi: 10.1094/PDIS-07-11-0550

Comstock, R. E., and Robinson, H. F. (1952). "Estimation of average dominance of genes," in Heterosis, 494-516. Available online at: https://www.cabdirect.org/ cabdirect/abstract/19531603854 (accessed December 25, 2020).

Courtney, M., Mcharo, M., La Bonte, D., and Gruneberg, W. (2008). Heritability estimates for micronutrient composition of sweetpotato storage roots. HortScience 43, 1382-1384. doi: 10.21273/hortsci.43.5.1382

David, M. C., Diaz, F. C., Mwanga, R. O. M., Tumwegamire, S., Mansilla, R. C., and Grüneberg, W. J. (2018). Gene pool subdivision of east african sweetpotato parental material. Crop Sci. 58, 2302-2314. doi: 10.2135/cropsci2017.11.0695

FAO (2017). FAOSTAT Database. Available online at: http://www.fao.org/faostat/ en/\#home

Field, C. B., Barros, V., Stocker, T. F., Dahe, Q., Jon Dokken, D., Ebi, K. L., et al. (2012). Managing the Risks of Extreme Events and Disasters to Advance Climate Change Adaptation: Special Report of the Intergovernmental Panel on Climate Change. Cambridge: Cambridge University Press.

Fischer, R. A., and Maurer, R. (1978). Drought resistance in spring wheat cultivars. I. Grain yield responses. Aust. J. Agric. Res. 29, 897-912. doi: 10.1071/AR9780897

Fretham, S. J. B., Carlson, E. S., and Georgieff, M. K. (2011). The role of iron in learning and memory. Adv. Nutr. 2, 112-121. doi: 10.3945/an.110.000190

Gemenet, D. C., da Silva Pereira, G., De Boeck, B., Wood, J. C., Mollinari, M., Olukolu, B. A., et al. (2020a). Quantitative trait loci and differential gene expression analyses reveal the genetic basis for negatively associated $\beta$-carotene 
and starch content in hexaploid sweetpotato [Ipomoea batatas (L.) Lam.]. Theor. Appl. Genet. 133, 23-36. doi: 10.1007/s00122-019-03437-7

Gemenet, D. C., Lindqvist-Kreuze, H., De Boeck, B., da Silva Pereira, G., Mollinari, M., Zeng, Z.-B., et al. (2020b). Sequencing depth and genotype quality: accuracy and breeding operation considerations for genomic selection applications in autopolyploid crops. Theor. Appl. Genet. 133, 3345-3363. doi: $10.1007 /$ s00122-020-03673-2

Gibson, R. W., Mpembe, I., Alicai, T., Carey, E. E., Mwanga, R. O. M., Seal, S. E., et al. (1998). Symptoms, aetiology and serological analysis of sweet potato virus disease in Uganda. Plant Pathol. 47, 95-102. doi: 10.1046/j.1365-3059.1998.00196.x

Gomes, M. (1996). Effects of drought and vine cutting management on the productivity of sweet potato in southern mozambique (Ph.D. thesis). Cranfield University, Cranfield, United Kingdom.

Grüneberg, W., Mwanga, R., Andrade, M., and Espinoza, J. (2009b). "Selection methods. Part 5: Breeding clonally propagated crops," in Plant Breeding and Farmer Participation, eds S. Ceccarelli, E. P. Guimarães, and E. Weltizien (Rome: FAO), 275-322.

Grüneberg, W., and Swanckaert, J. (2019). A Breakthrough: Hybrid Population Breeding Validated in Peru, Uganda, and Mozambique. SASHA Brief. No. 2. Lima: CIP. Available at: https://hdl.handle.net/10568/105971

Grüneberg, W. J., Eyzaguirre, R., Diaz, F., Boeck, B. de, Espinoza, J., Mwanga, R. O. M., et al. (2019). Procedures for the Evaluation of Sweetpotato Trials. Lima: CIP.

Grüneberg, W. J., Eyzaguirre, R., Espinoza, J., Mwanga, R. O. M., Andrade, M., Dapaah, H., et al. (2009a). Procedures for the Evaluation and Analysis of Sweetpotato Trials. Lima: CIP.

Grüneberg, W. J., Ma, D., Mwanga, R. O. M., Carey, E. E., Huamani, K., Diaz, F., et al. (2015). "Advances in sweetpotato breeding from 1992 to 2012," in Potato and Sweetpotato in Africa: Transforming the Value Chains for Food and Nutrition Security (Wallingford, CT: CABI), 3-68, doi: 10.1079/9781780644202.0003

Grüneberg, W. J., Manrique, K., Zhang, D., and Hermann, M. (2005). Genotype $\mathrm{x}$ environment interactions for a diverse set of sweetpotato clones evaluated across varying ecogeographic conditions in Peru. Crop Sci. 45, 2160-2171. doi: $10.2135 /$ cropsci2003.0533

Hahn, S. K. (1982). "Research priorities, techniques, and accomplishments in sweet potato breeding at IITA," in Root Crops in Eastern Africa: Proceedings of a Workshop Held in Kigali, Rwanda, 23-27 November 1980 (Ottawa, ON: IDRC), 23-26.

Hahn, S. K., Isoba, J. C. G., and Ikotun, T. (1989). Resistance breeding in root and tuber crops at the International Institute of Tropical Agriculture (IITA), Ibadan, Nigeria. Crop Prot. 8, 147-168. doi: 10.1016/0261-2194(89)90022-7

Hahn, S. K., Terry, E., and Leuschner, K. (1981). Resistance of sweet potato to virus complex. HortScience 16, 535-537.

Hotz, C., Loechl, C., Lubowa, A., Tumwine, J. K., Ndeezi, G., Nandutu Masawi, A., et al. (2012). Introduction of $\beta$-carotene-rich orange sweet potato in rural uganda resulted in increased vitamin a intakes among children and women and improved vitamin A status among children. J. Nutr. 142, 1871-1880. doi: $10.3945 /$ jn.111.151829

Jongstra, R., Mwangi, M. N., Burgos, G., Zeder, C., Low, J. W., Mzembe, G., et al. (2020). Iron Absorption from iron-biofortified sweetpotato is higher than regular sweetpotato in Malawian women while iron absorption from regular and iron-biofortified potatoes is high in Peruvian women. J. Nutr. 150, 3094-3102. doi: 10.1093/jn/nxaa267

Karyeija, R. F., Gibson, R. W., and Valkonen, J. P. T. (1998). The significance of sweet potato feathery mottle virus in subsistence sweet potato production in Africa. Plant Dis. 82, 4-15. doi: 10.1094/PDIS.1998.82.1.4

Kays, S. J., Wang, Y., and McLaurin, W. J. (2005). Chemical and geographical assessment of the sweetness of the cultivated sweetpotato clones of the world. J. Am. Soc. Hortic. Sci. 130, 591-597. doi: 10.21273/jashs.130.4.591

Laryea, D., Wireko-Manu, F. D., and Oduro, I. (2018). Formulation and characterization of sweetpotato-based complementary food. Cogent. Food Agric. 4:1517426. doi: 10.1080/23311932.2018.1517426

Laurie, R., Phillipus, C., Plooy, D., Laurie, R. N., Laurie, S. M., Du Plooy, C. P., et al. (2015a). Yield of drought-stressed sweet potato in relation to canopy cover, stem length and stomatal conductance. Artic. J. Agric. Sci. 7, 201-214. doi: $10.5539 /$ jas.v7n1p201
Laurie, S. M., Booyse, M., Labuschagne, M. T., and Greyling, M. M. (2015b). Multienvironment performance of new orange-fleshed sweetpotato cultivars in South Africa. Crop Sci. 55, 1585-1595. doi: 10.2135/cropsci2014. 09.0664

Laurie, S. M., Calitz, F. J., Adebola, P. O., and Lezar, A. (2013). Characterization and evaluation of South African sweet potato (Ipomoea batatas (L.) LAM) land races. South African J. Bot. 85, 10-16. doi: 10.1016/j.sajb.2012.11.004

Legg, J., Okonya, J., and Coyne, D. (2017). "Integrated pest management of root and tuber crops in the tropics," in Integrated pest management in tropical regions, eds C. Rapisarda and G. E. M. Cocussa (Wallingford, CT: CAB International), 90-112. doi: 10.1079/9781780648002.0090

Lodhi, M. A., Ye, G.-N., Weeden, N. F., and Reisch, B. I. (1994). A simple and efficient method for DNA extraction from grapevine cultivars and Vitis species. Plant Mol. Biol. Report. 12, 6-13. doi: 10.1007/BF02668658

Low, J., Lynam, J., Lemaga, B., Crissman, C., Barker, I., Thiele, G., et al. (2009). "Sweetpotato in Sub-Saharan Africa," in The Sweetpotato, eds G. Loebenstein and G. Thottappilly (Dordrecht: Springer), 359-390. doi: 10.1007/978-1-4020-9475-0_16

Low, J. W., Arimond, M., Osman, N., Cunguara, B., Zano, F., and Tschirley, D. (2007). A food-based approach introducing orange-fleshed sweet potatoes increased vitamin A intake and serum retinol concentrations in young children in rural Mozambique. J. Nutr. 137, 1320-1327. doi: 10.1093/jn/137.5.1320

Low, J. W., Ortiz, R., Vandamme, E., Andrade, M., Biazin, B., and Grüneberg, W. J. (2020). Nutrient-dense orange-fleshed sweetpotato: advances in droughttolerance breeding and understanding of management practices for sustainable next-generation cropping systems in Sub-Saharan Africa. Front. Sustain. Food Syst. 4:50. doi: 10.3389/fsufs.2020.00050

Ludlow, M. M., and Muchow, R. C. (1990). A critical evaluation of traits for improving crop yields in water-limited environments. Adv. Agron. 43, 107-153. doi: 10.1016/S0065-2113(08)60477-0

Makunde, G. S., Andrade, M. I., Menomussanga, J., and Grüneberg, W. (2018). Adapting sweetpotato production to changing climate in Mozambique. Open Agric. 3, 122-130. doi: 10.1515/opag-2018-0012

Makunde, G. S., Andrade, M. I., Ricardo, J., Alvaro, A., Menomussanga, J., and Gruneberg, W. (2017). Adaptation to mid-season drought in a sweetpotato (Ipomoea batatas [L.] Lam) germplasm collection grown in Mozambique. Open Agric. 2, 133-138. doi: 10.1515/opag-2017-0012

Möhring, J., and Piepho, H. P. (2009). Comparison of weighting in two-stage analysis of plant breeding trials. Crop Sci. 49, 1977-1988. doi: $10.2135 /$ cropsci2009.02.0083

Mollinari, M., and Garcia, A. A. F. (2019). Linkage analysis and haplotype phasing in experimental autopolyploid populations with high ploidy level using Hidden Markov Models. G3 Genes Genomes Genet. 9, 3297-3314. doi: $10.1534 / \mathrm{g} 3.119 .400378$

Mollinari, M., Olukolu, B. A., Pereira, G. S., Khan, A., Gemenet, D., Yencho, G. C., et al. (2020). Unraveling the hexaploid sweetpotato inheritance using ultra-dense multilocus mapping. G3 Genes Genomes Genet. 10, 281-292. doi: $10.1534 / \mathrm{g} 3.119 .400620$

Mwanga, R. O. M., Mayanja, S., Swanckaert, J., Nakitto, M., zum Felde, T., Grüneberg, W., et al. (2021). Development of a food product profile for boiled and steamed sweetpotato in Uganda for effective breeding. Int. J. Food Sci. Technol. 56, 1385-1389. doi: 10.1111/ijfs. 14792

Mwanga, R. O. M., Niringiye, C., Alajo, A., Kigozi, B., Namukula, J., Mpembe, I., et al. (2011). 'NASPOT 11', a sweetpotato cultivar bred by a participatory plant-breeding approach in Uganda. HortScience 46, 317-321. doi: 10.21273/HORTSCI.46.2.317

Mwanga, R. O. M., Odongo, B., Niringiye, C., Alajo, A., Kigozi, B., Makumbi, R., et al. (2009). 'NASPOT 7', 'NASPOT 8', 'NASPOT 9 O', 'NASPOT 10 O', and 'Dimbuka-Bukulula' Sweetpotato. HortScience 44, 828-832. doi: 10.21273/HORTSCI.44.3.828

Mwanga, R. O. M., Tugume, J., Kreuze, J., Segundo, F., Grüneberg, W. J., and G. N. Ssemakula, G. N. (2015). "Discrimination of sweetpotato virus disease resistant and tolerant clones," in Plant and Animal Genome XXIII Conference (San Diego, CA). Available online at: https://pag.confex.com/pag/xxiii/webprogram/ Paper17824.html

Mwanga, R. O. M., Yencho, G. C., Gibson, R. W., and Moyer, J. W. (2013). Methodology for inoculating sweetpotato virus disease: discovery of tip 
dieback, and plant recovery and reversion in different clones. Plant Dis. 97, 30-36. doi: 10.1094/PDIS-12-11-1072-RE

Omotobora, B. O., Adebola, P. O., Modise, D. M., Laurie, S. M., and Gerrano, A. S. (2014). Greenhouse and field evaluation of selected sweetpotato (Ipomoea batatas (L.) LAM) accessions for drought tolerance in South Africa. Am. J. Plant Sci. 5, 3328-3339. doi: 10.4236/ajps.2014.521348

Onwueme, I., and Charles, W. (1994). Tropical Root and Tuber Crops: Production, Perspectives and Future Prospects. Rome: FAO.

Passioura, J. B. (1977). Grain yield, harvest index, and water use of wheat. J. Aust. Inst. Agric. Sci. 43, 117-120.

Pereira, G. da S., Gemenet, D. C., Mollinari, M., Olukolu, B. A., Wood, J. C., Diaz, F., et al. (2020). Multiple QTL mapping in autopolyploids: a randomeffect model approach with application in a hexaploid sweetpotato full-sib population. Genetics 215, 579-595. doi: 10.1534/genetics.120.303080

Pereira, G. S., Garcia, A. A. F., and Margarido, G. R. A. (2018). A fully automated pipeline for quantitative genotype calling from next generation sequencing data in autopolyploids. BMC Bioinformatics 19:398. doi: 10.1186/s12859-018-2433-6

Porras, E., Burgos, G., Sosa, P., and zum Felde, T. (2014). Procedures for Sampling and Sample Preparation of Sweetpotato Roots and Potato Tubers for Mineral Analysis. Lima: CIP.

Ramirez-Vallejo, P., and Kelly, J. D. (1998). Traits related to drought resistance in common bean. Euphytica 99, 127-136. doi: 10.1023/A:1018353200015

Ravi, K., Vadez, V., Isobe, S., Mir, R. R., Guo, Y., Nigam, S. N., et al. (2011). Identification of several small main-effect QTLs and a large number of epistatic QTLs for drought tolerance related traits in groundnut (Arachis hypogaea L.). Theor. Appl. Genet. 122, 1119-1132. doi: 10.1007/s00122-010-1517-0

Rife, T. W., and Poland, J. (2014). Field book: an open-source application for field data collection on Android. Crop Sci. 54, 1624-1627. doi: 10.2135/cropsci2013.08.0579

Roohani, N., Hurrell, R., Kelishadi, R., and Schulin, R. (2013). Review on zinc and its importance for human health. J. Res. Med. Sci. 18, 144-157.

Rosielle, A. A., and Hamblin, J. (1981). Theoretical aspects of selection for yield in stress and non-stress environment. Crop Sci. 21, 943-946. doi: 10.2135/cropsci1981.0011183X002100060033x

SAS (1997). SAS/STAT Software, Changes and Enhancements Through Release 6.12. Cary, NC: SAS

Serang, O., Mollinari, M., and Garcia, A. A. F. (2012). Efficient exact maximum $a$ posteriori computation for Bayesian SNP genotyping in polyploids. PLoS ONE 7:e0030906. doi: 10.1371/journal.pone.0030906

Singh, M., Malhotra, R. S., Ceccarelli, S., Sarker, A., Grnado, S., and Erskine, W. (2003). Spatial variability models to improve dryland field trials. Exp. Agric. 39, 151-160. doi: 10.1017/S0014479702001175

Siwela, M., Pillay, K., Govender, L., Lottering, S., Mudau, F. N., Modi, A. T., et al. (2020). Biofortified crops for combating hidden hunger in south africa: availability, acceptability, micronutrient retention and bioavailability. Foods 9:815. doi: 10.3390/foods9060815

Thiele, G., Dufour, D., Vernier, P., Mwanga, R. O. M., Parker, M. L., Schulte Geldermann, E., et al. (2021). A review of varietal change in roots, tubers and bananas: consumer preferences and other drivers of adoption and implications for breeding. Int. J. Food Sci. Technol. 56, 1076-1092. doi: 10.1111/ijfs.14684

Tumwegamire, S., Kapinga, R., Rubaihayo, P. R., Labonte, D. R., Grüneberg, W. J., Burgos, G., et al. (2011). Evaluation of dry matter, protein, starch, sucrose, $\beta$-carotene, iron, zinc, calcium, and magnesium in East African sweetpotato [Ipomoea batatas (L.) Lam] germplasm. HortScience 46, 348-357. doi: 10.21273 /hortsci.46.3.348

Valkonen, J. P. T., Kreuze, J. F., and Ndunguru, J. (2015). "Disease management, especially viruses in potato and sweetpotato," in Potato and Sweetpotato in Africa: Transforming the Value Chains for Food and Nutrition Security, eds J. Low, N. Moses, S. Quinn, and M. Parker (Wallingford, CT: CAB International), 339-349. doi: 10.1079/9781780644202.0339

van Jaarsveld, P. J., Faber, M., Tanumihardjo, S. A., Nestel, P., Lombard, C. J., and Benadé, A. J. S. (2005). $\beta$-Carotene-rich orange-fleshed sweet potato improves the vitamin A status of primary school children assessed with the modified-relative-dose-response test. Am. J. Clin. Nutr. 81, 1080-1087. doi: 10.1093/ajcn/81.5.1080

Wadl, P. A., Olukolu, B. A., Branham, S. E., Jarret, R. L., Yencho, G. C., and Jackson, D. M. (2018). Genetic diversity and population structure of the USDA sweetpotato (Ipomoea batatas) germplasm collections using GBSpoly. Front. Plant Sci. 9:1166. doi: 10.3389/fpls.2018.01166

Wiesmann, D., Biesalski, H., von Grebmer, K., and Bernstein, J. (2015). Methodological review and revision of the Global Hunger Index. SSRN Electron. J. doi: 10.2139/ssrn.2673491

Wu, S., Lau, K. H., Cao, Q., Hamilton, J. P., Sun, H., Zhou, C., et al. (2018). Genome sequences of two diploid wild relatives of cultivated sweetpotato reveal targets for genetic improvement. Nat. Commun. 9:4580. doi: 10.1038/s41467-018-06983-8

Yada, B., Alajo, A., Ssemakula, G. N., Brown-Guedira, G., Otema, M. A., Stevenson, P. C., et al. (2017a). Identification of simple sequence repeat markers for sweetpotato weevil resistance. Euphytica 213, 1-12. doi: 10.1007/s10681-017-1917-1

Yada, B., Alajo, A., Ssemakula, G. N., Mwanga, R. O. M., Brown-Guedira, G., and Yencho, G. C. (2017b). Selection of simple sequence repeat markers associated with inheritance of sweetpotato virus disease resistance in sweetpotato. Crop Sci. 57, 1421-1430. doi: 10.2135/cropsci2016.08.0695

Yang, J., Moeinzadeh, M.-H., Kuhl, H., Helmuth, J., Xiao, P., Haas, S., et al. (2017). Haplotype-resolved sweet potato genome traces back its hexaploidization history. Nat. Plants 3, 696-703. doi: 10.1038/s41477-017-0002-z

Zou, F., Fine, J. P., Hu, J., and Lin, D. Y. (2004). An efficient resampling method for assessing genome-wide statistical significance in mapping quantitative trait loci. Genetics 168, 2307-2316. doi: 10.1534/genetics.104.031427

Conflict of Interest: The authors declare that the research was conducted in the absence of any commercial or financial relationships that could be construed as a potential conflict of interest.

Copyright (c) 2021 Mwanga, Swanckaert, da Silva Pereira, Andrade, Makunde, Grüneberg, Kreuze, David, De Boeck, Carey, Ssali, Utoblo, Gemenet, Anyanga, Yada, Chelangat, Oloka, Mtunda, Chiona, Koussao, Laurie, Campos, Yencho and Low. This is an open-access article distributed under the terms of the Creative Commons Attribution License (CC BY). The use, distribution or reproduction in other forums is permitted, provided the original author(s) and the copyright owner(s) are credited and that the original publication in this journal is cited, in accordance with accepted academic practice. No use, distribution or reproduction is permitted which does not comply with these terms. 